\title{
Phenomenology of Sexual Dysfunctions in Chemical Warfare Victims of Sardasht City
}

\section{ART ICLE IN F O}

Article Type

Qualitative Study

\section{Authors}

Melkari B. ${ }^{1} M S c$,

Farahbakhsh K.*1 $P h D$,

Farrokhi N. ${ }^{2} P h D$,

Motamedi A. ${ }^{3} \mathrm{PhD}$

How to cite this article
Melkari B, Farahbakhsh K, Farr-
okhi N, Motamedi A. Phenom-
enology of Sexual Dysfunctions in
Chemical Warfare Victims of Sard-
asht City. Iranian Journal of War \&
Public Health.2020;12(1):63-73.

\begin{abstract}
A B S T R A C T
Aims Sexual dysfunction is one of the most important factors that can play a fundamental role in the individual and social health and adjustment of people. Chemical injury is one of the cases that can be considered as a serious factor in the occurrence or aggravation of sexual dysfunction by causing organic and psychological changes in male and female victims. The purpose of this study was to identify sexual dysfunctions in chemical warfare victims in Sardasht city.

Participants \& Methods This qualitative phenomenological research was carried out in 2018 using grounded theory method among all chemical warfare victims in Sardasht city. At first, Hurlbert Index of Sexual Desire (HISD) was distributed among the identified individuals and 60 chemical victims ( 30 females and 30 males) with low score were selected by purposive sampling method for participation in the study. Semi-structured interviews were used to collect data. All interviews were recorded and then transcribed, and finally the data were analyzed using the Colaizzi's seven step process and grounded theory method Findlings The core code for "multiple sexual disfunctions" included 9 selected codes. Selected codes were identified with their primary and secondary concepts.

Conclusion Identified sexual disfunctions include disorder in initiating sexual relations, lack of sexual arousal, lack of perception of sexual pleasure, sexual organ dysfunction, lack of sexual desire, impotency, erectile dysfunction, multi-faceted disorder in ejaculation and masturbation.
\end{abstract}

Keywords Sexual Dysfunction; Chemical Warfare; Victims; Phenomenology
${ }^{1}$ Counseling Department, Psychology \& Educational Sciences Faculty, Allameh Tabataba'i University, Tehran, Iran

${ }^{2}$ Measurement \& Measurement Department, Psychology \& Educational Sciences Faculty, Allameh Tabataba'I University, Tehran, Iran

${ }^{3}$ Clinical Psychology Department, Psychology \& Educational Sciences Faculty, Allameh Tabataba'i University, Tehran, Iran

\section{${ }^{*}$ Correspondence}

Address: Counseling Department, Psychology \& Educational Sciences Faculty, Allameh Tabataba'i University, Dehkadeh Olampik, Tehran, Iran. Postal Code: 1489684511 Phone: +98 (21) 48390000

Fax: +98 (21) 48390000 kiiumars@yahoo.com

\section{Article History}

Received: August 18, 2018

Accepted: December 15, 2018

ePublished: March 17, 2020

\section{T A T I O N L I N K S}

Generalities and basics of ... [2] Chemical, microbial and nuclear weapons and ways .. Iraq's use of chemical weapons against ... [4] The role of negative interpretations of intrusive ... [5] Evaluation of serum levels of nitric oxide in chemical victims ... [6] The limitation of chemical and biological ... [7] Sexual disorders in male and ... [8] The effect of chemical weaponry on ... [9] Study of sleep quality in chemical ... [10] Clinical handbook of psychological disorder ... [11] Study of sexual problems resulting from ... [12] Sexual dysfunction disorders and their ... [13] Kaplan and Sadock's synopsis of psychiatry ... [14] Sexual well-being, happiness, and satisfaction ... [15] Sexual function and quality of life in the male ... [16] Impact of infertility on quality of life ... [17] Infertility: a label of choice in the case ... [18] Psychological- social consequences chemical ... [19] Female sexual desire disorders--prevalence ... [20] Female sexual desire disorders ... [21] Sexual problems and dysfunction: epidemiology ... [22] Sexual function in chronic ... [23] Gender representation in illustrations ... [24] Intimate matters: a history of sexuality ... [25] Sexual obsessions and clinical correlates in ... [26] Epidemiology/risk factors of sexual ... [27] A systematic review of sexual ... [28] A systematic review of sexual ... [29] Neuropsychological status in chemical warfare ... [30] Halbert index of sexual desire (HISD) ... [31] The encyclopedia of ... [32] The Effectiveness of cognitive ... [33] Psychological and interpersonal ... [34] Womens sexual ... [35] Sexual desire and relationship ... [36] Use of the Italian translation of the ... [37] Investigation of the mental status of ... [38] A survey on the relative frequency ... [39. Sexual dysfunction in male and ... [40] Examining the problems and complaints ... [41] Vicarious PTSD in Sardasht chemical ... [42] A health care guide for chemical warfare victims ... 
مختلفى را به كار كَرفتهاند. يكى از اين ابزارها استفاده از سموم و و

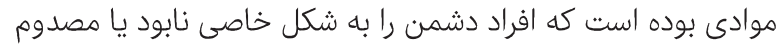

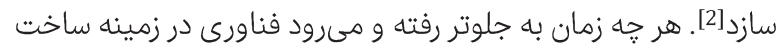

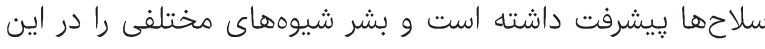

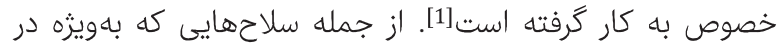
سده اخير به كار رفته است، سلاحهاى هستهاي، شيميايى و وانئ

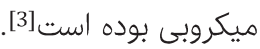

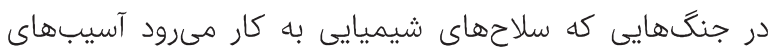

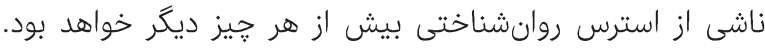

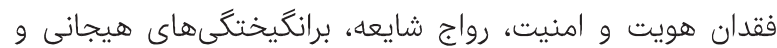

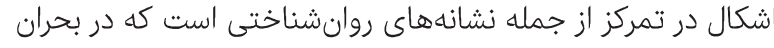

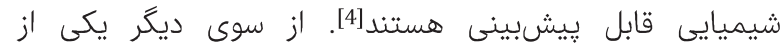
شاخصهاى مهم مرتبط با سلامت، سلامت جنسى و ونسي نقطه مقابل

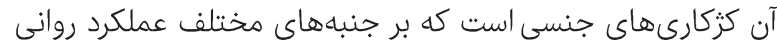

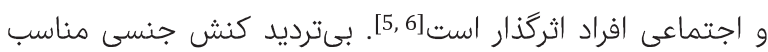
سهم بسزايى در بهداشت و سلامت كلى افراد ايفا مىكندارئ.

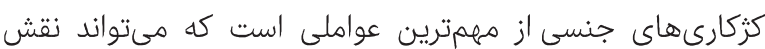

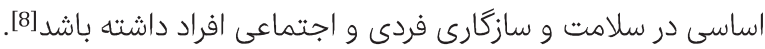

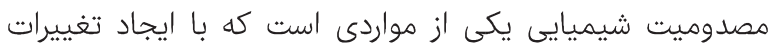

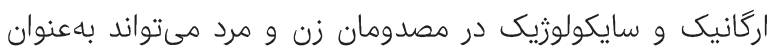

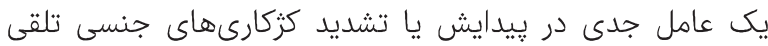

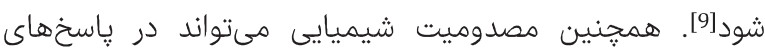

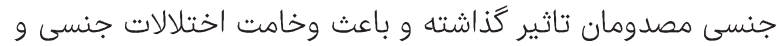

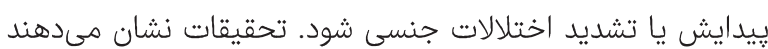

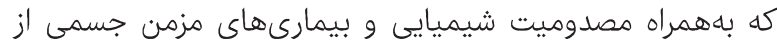

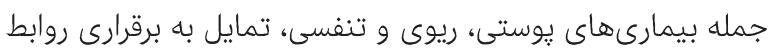

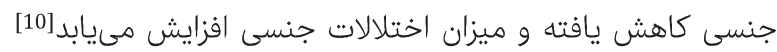
كه اين موضوع مىتواند باعث بِيدايش نابسامانىهاى قابل توجهى در روابط فردى و اجتماعى شود [11].

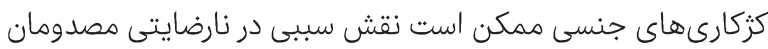

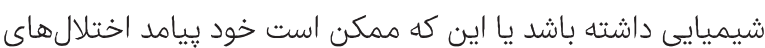

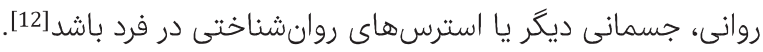

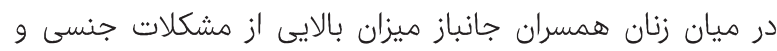

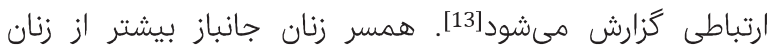

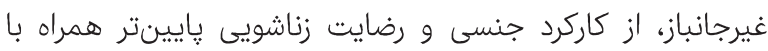
كاهش سطح آندروزن خون شكايت ميى كنند

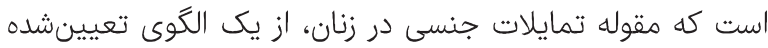

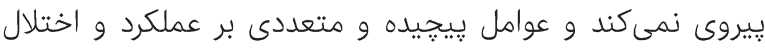

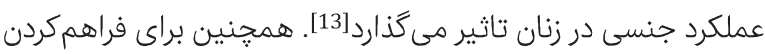

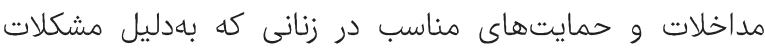

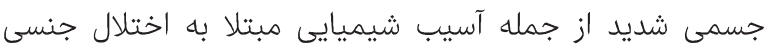

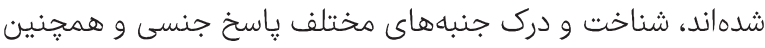

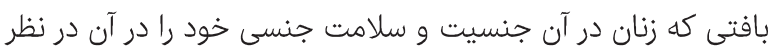
مى بيرند، ضرورى است [16]. اين در حالى است كه به دلايل تاريخى،

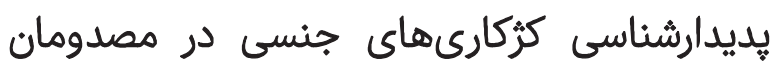
شيميايى شهر سردشت

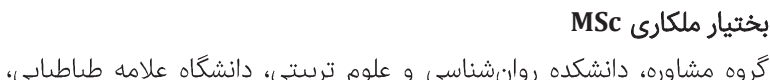
تمبران، ايران

ShD "كيومرث فرحبخش

گروه مشاوره، دانشكده روانشناسى و علوم تربيتى، دانشخاه علامه طباطبايى، تهران، ايران

Pورعلى فرخى PhD

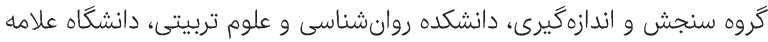
طباطبايى، تهران، ايران

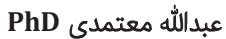
گروه روانشناسى بالينى، دانشكده روانشناسى و علوم تربيتى، دانشگًاه علامه طباطبايى، تهران، ايران

جكيده

اهداف: كزكارىهاى جنسى از مهمترين عواملى است كه مىتواند نقش اساسى

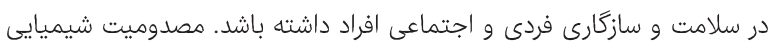

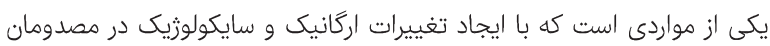

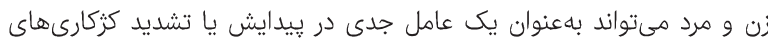

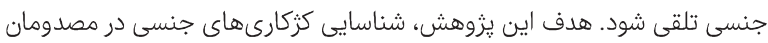
شيميايى شهر سردشت بود.

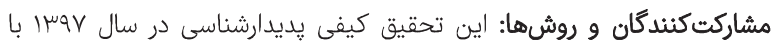

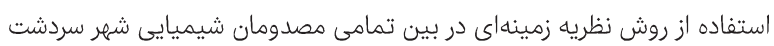

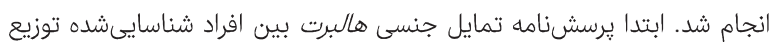

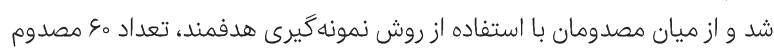

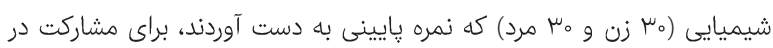

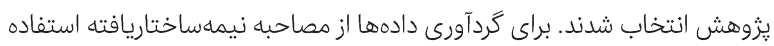

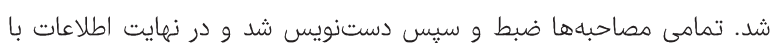
استفاده از الخوى هفتمرحلهاى نظريه زمينهاى كلايزر مورد تجزيه و تحليل قرار

كرفت.

يافتهها: كد محورى "كزكارىهاى جنسى خندگًانه" دربرگيرنده 9 كد انتخابى بود.

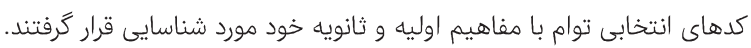
نتيجه گيرى: كزكارىهاى جنسى شناسايى شده شامل خلل در در آغازگرى روابط

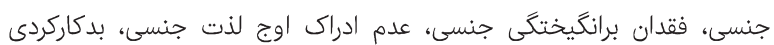

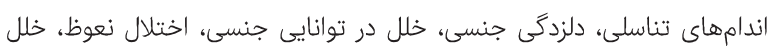

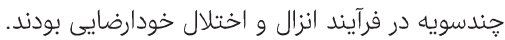

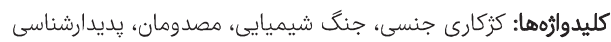

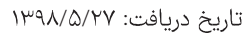
تاريخ קذيرش: تاريخ درياف:

kiiumars@yahoo.com : نويسنده مسئول: vلائر:

مقلهم

جنگ، بخشى جدانشدنى از زندگى اجتماعى انسانها است و همواره در طول تاريخ وجود داشته و صدمات جبرانانايذيرى بر جنبهانهاى مختلف سلامت جسمى، فردى، خانوادگى و اجتماعى انسانها وارد

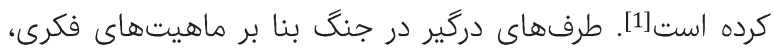

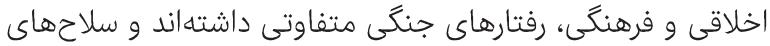


بيشتر به جنبههاى جسمانى اين بيماران يرداختهاند و دوان در اين ميان

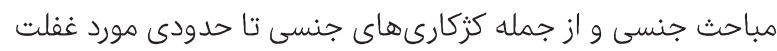

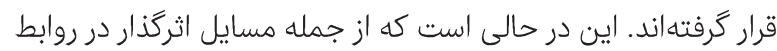

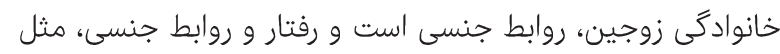

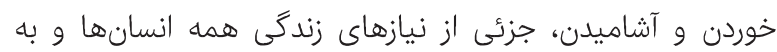

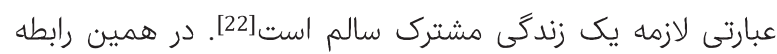

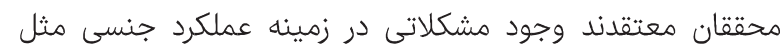

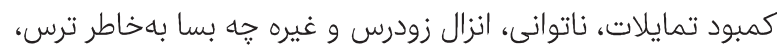

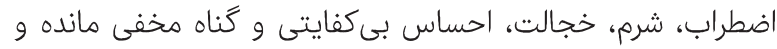

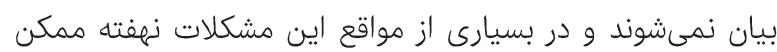

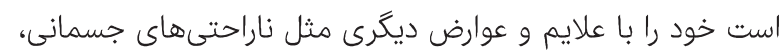

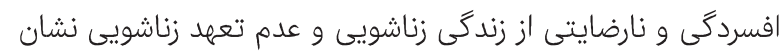

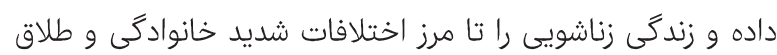

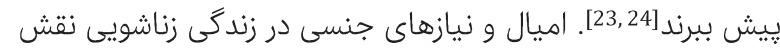

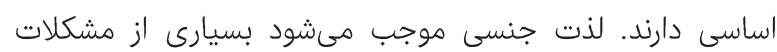

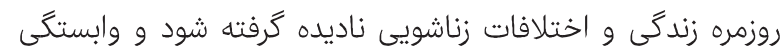

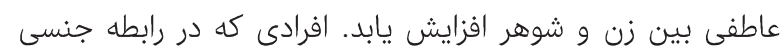

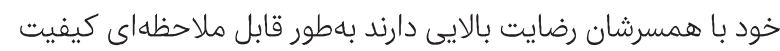

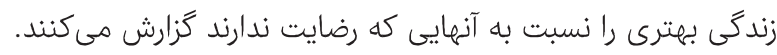

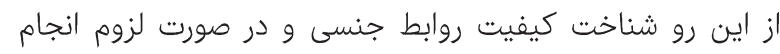

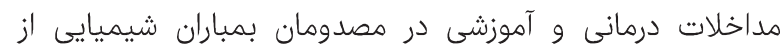

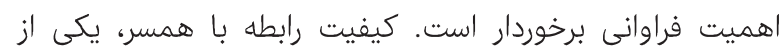

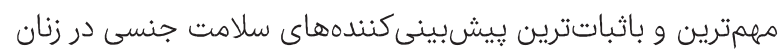

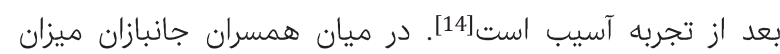

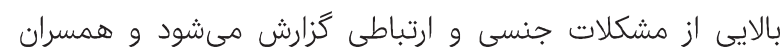

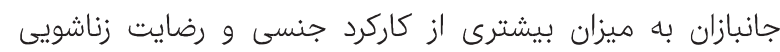

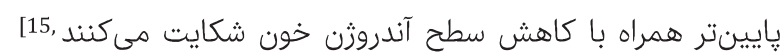

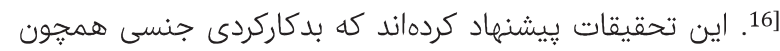

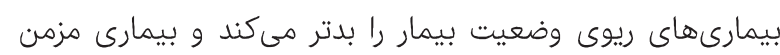

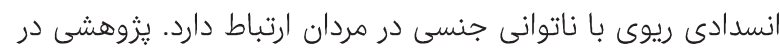

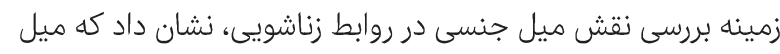

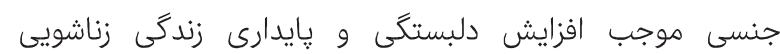

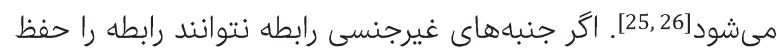

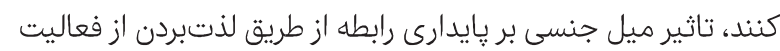

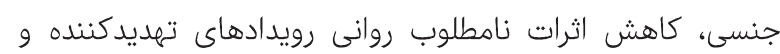

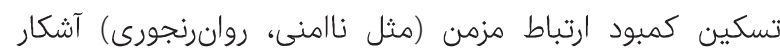

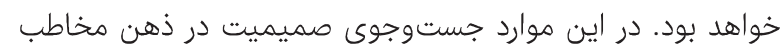
جنسى ممكن است راهى جايكزين و جبرانى براى تحقق نيازهاى دلبستخى براى عشق و اطمينان فراهم كند.

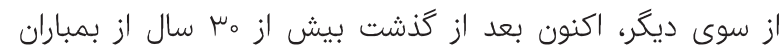

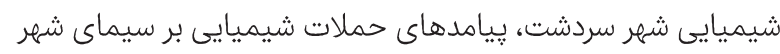

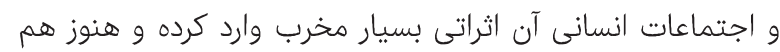

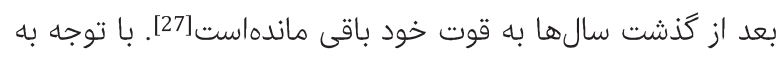

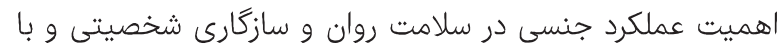

اجتماعى، سياسى و مذهبى، حيطه سلامت جنسى زنان، از حيطه

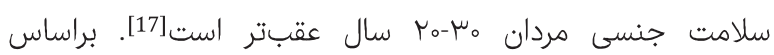

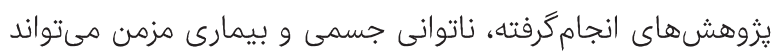

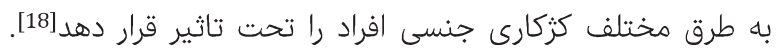

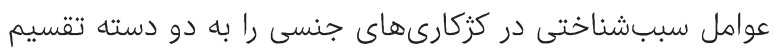

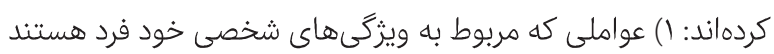

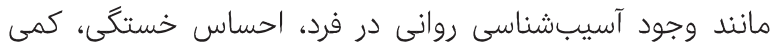

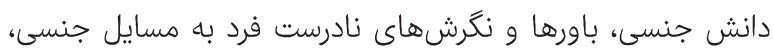

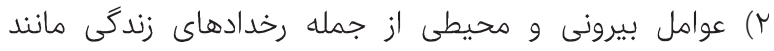
ضربههاى جسمى و روانى، جنگ و و بمباران شيميايى.

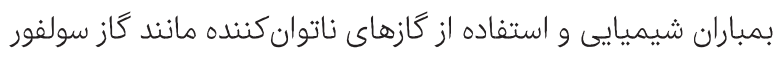

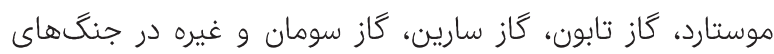

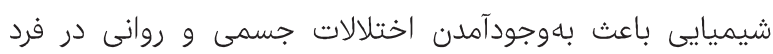
مصدوم مىشود[3]. از جمله اختلالات جسمانى ناشى از ازئل بمباران

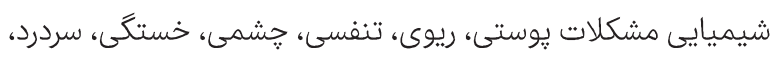

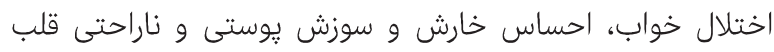

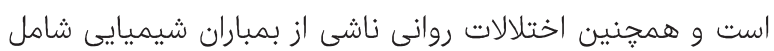

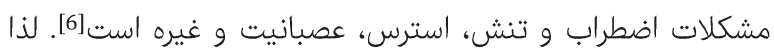

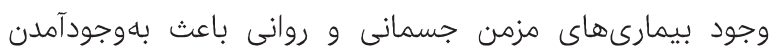

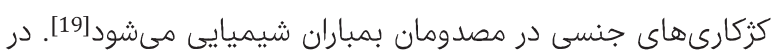

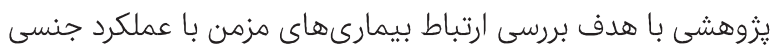

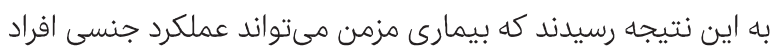

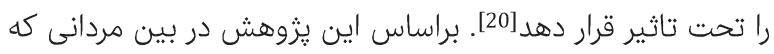

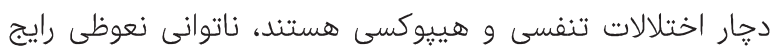

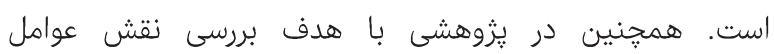

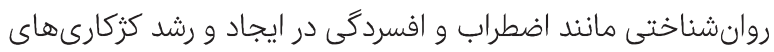

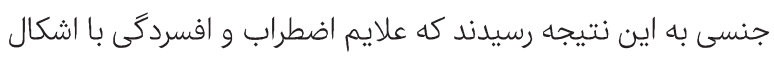

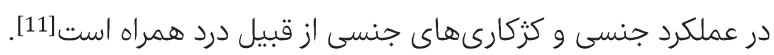

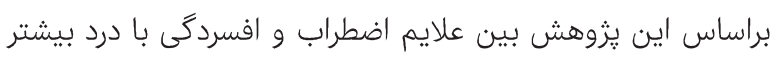

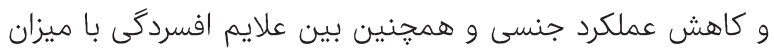

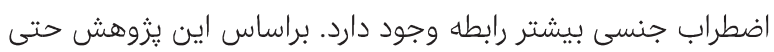

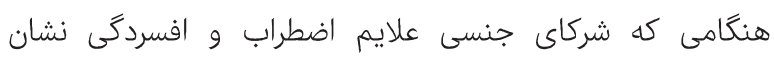

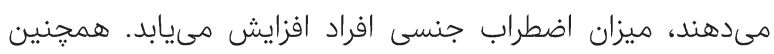

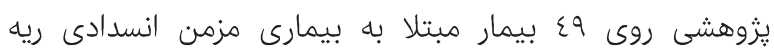

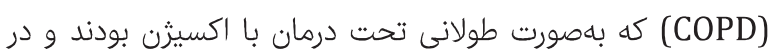

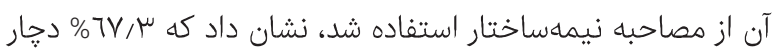

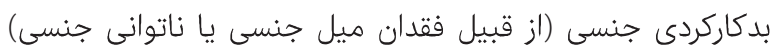

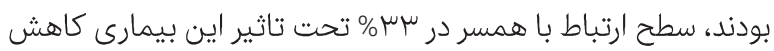

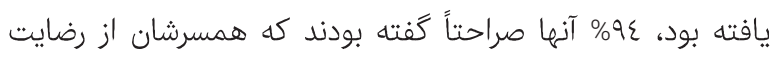
جنسى كمترى برخوردار است كه علت آن را مشكلات ارتباطى بئنار

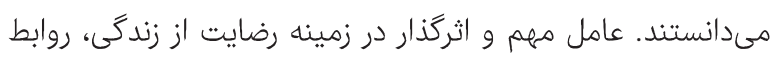

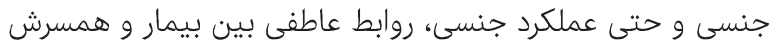

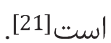
يزوهشهاى انجامرَرفته روى مصدومان بمباران شيميايى، تاكنون 
r r سئوال است كه در يك مقياس ليكرت ينجدرجهاى (هميشه،

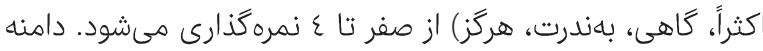

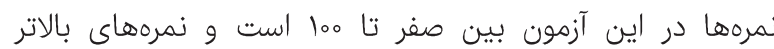

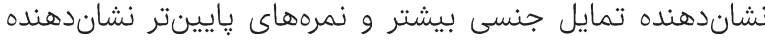

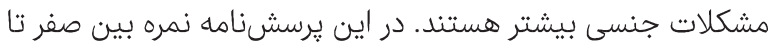

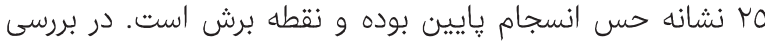

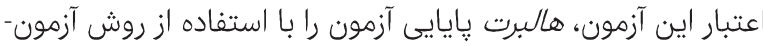

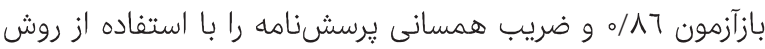

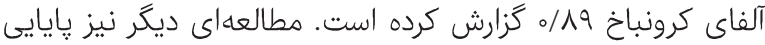

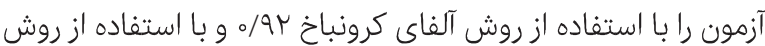

$$
\text { دونيمهكردن ا9/ه به دست آورده است] [29]. }
$$

r- مصاحبه نيمهساختاريافته: براى بررسى اختلالات كزّكارىهاى

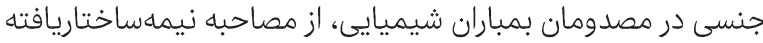

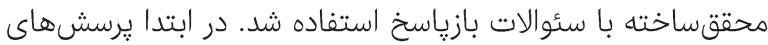
مصاحبه براساس كزكارىهاى جنسى، تعريف مساله، مطالعات

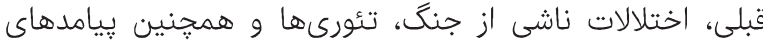

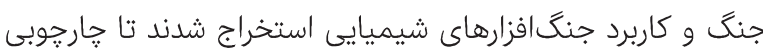

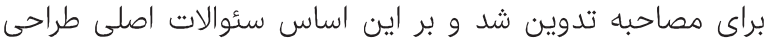
شد. در مرحله بعد يِ إس از بررسى محتواى سئوالات مصاحبه إسيه

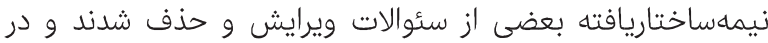

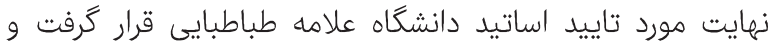

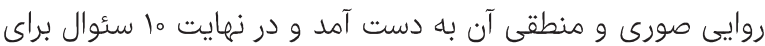

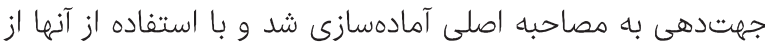
شركتكنندكان مصاحبه نيمهساختاريافته به عمل آمد. محورهاى

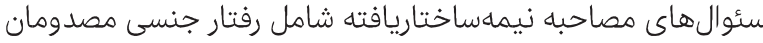

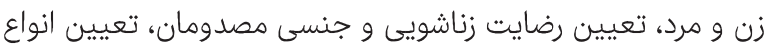
كزكارىهاى جنسى مصدومان شيميايى، تعيين انواع مشكلات

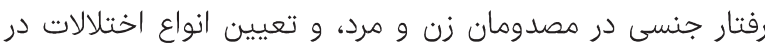

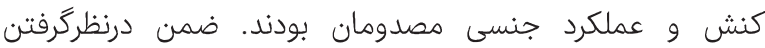

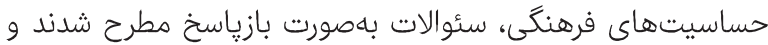

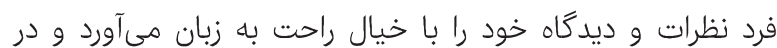
ياسخكويى به سئوالات هيج محدوديتى نداشتند ف30].

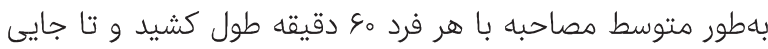

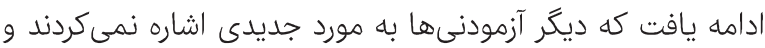

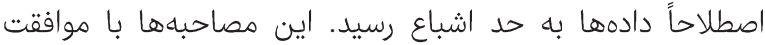

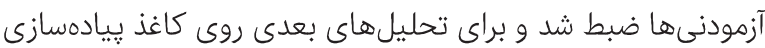

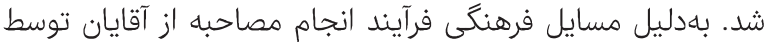

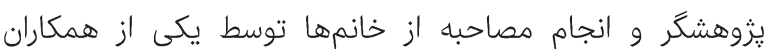
متخصص خانم در اين رابطه انجام گرفت. روند اجراى مصائ مصاحبه

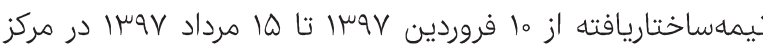
مشاوره "نسيم آرامش"، يا منزل و محل كار مصدومان اندان شيميايى اجرا شد. دشوارى در جلب اعتماد مصدومان شيميايى زن در فرآئ فرآيند

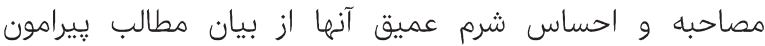

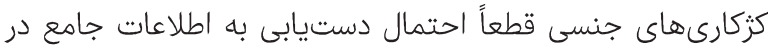

درنظركرفتن اين امر كه بيشتر بزوهش هارهاى انجامشده در اين زمينه،

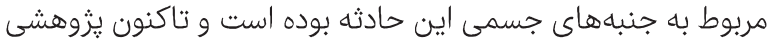

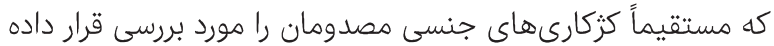

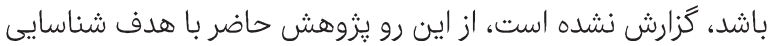
انواع كزُكارىهاى جنسى در مصدومان شيميايى انجام شد.

\section{مشاركت كنندگان و روشها}

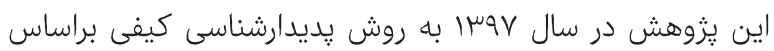

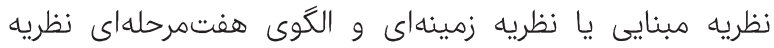
زمينهاى كلايزر[28] انجام شد. جامعه مورد مطالعه آسيبديدكان بمباران شيميايى شهر سردشت بود كه در تيرماه عوبسا توسط عراق

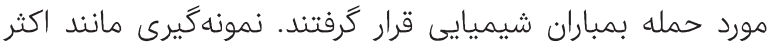

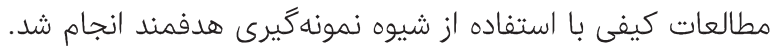
براى اين منظور، به اداره بنياد شهيد و امور ايثاركران شهرستان إنان

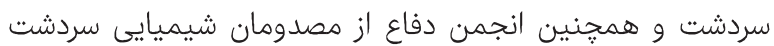

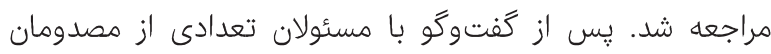

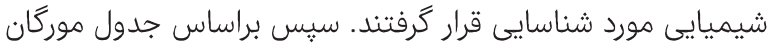

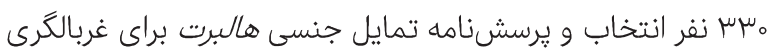

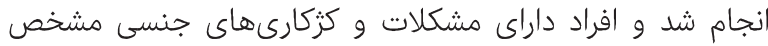

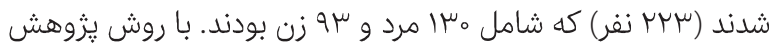

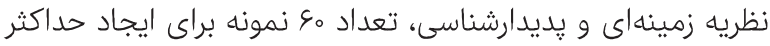

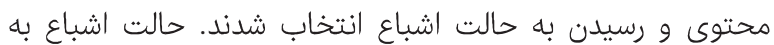

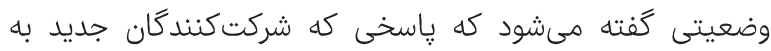

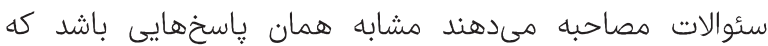

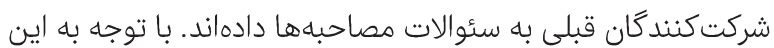

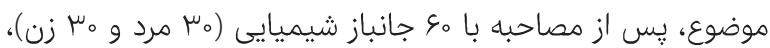

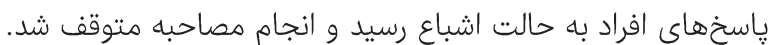

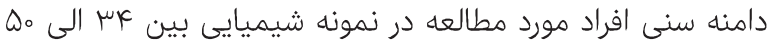

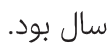
با اولين مصدومان شيميايى كه بهطور هدفمند انتخاب شدند يس

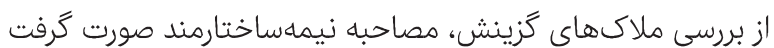

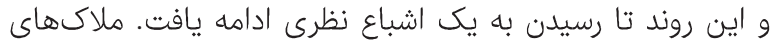

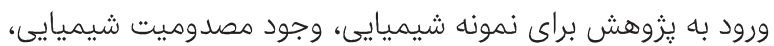

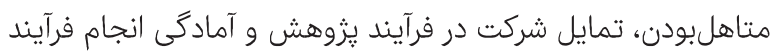

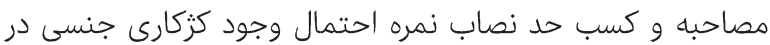
يرسشنامه تمايل جنسى هالبرت (كسب امتياز بين صفر تا هـ) [29]. اطلاعات جمعيتشناسى از جمله سن، سطح تحصيلات، درائن درصد جانبازى، وضعيت اشتغال و تعداد فرزندان نيز جمعآورى شد. از دو ابزار زير بهعنوان ابزار يُزوهش استفاده شد: ا- برسشنامه تمايل جنسى هالبرت (HISD): يرسشنار برنامه تمايل

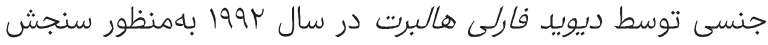

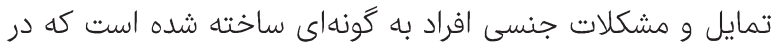

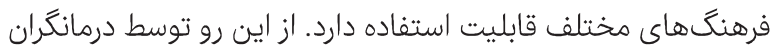

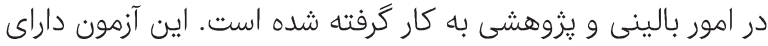




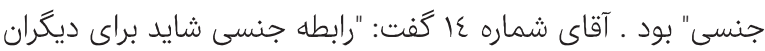

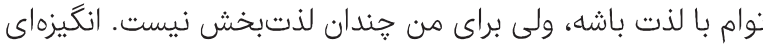
براى برقراركردنش ندارم. هيج علاقهاى هم بعش ندائ ندارم". آقاى شماره

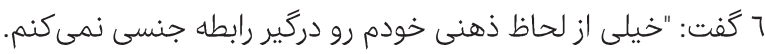

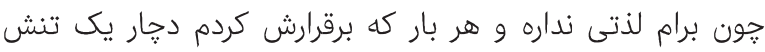

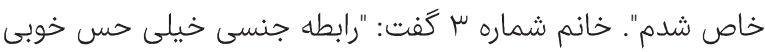

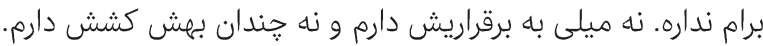

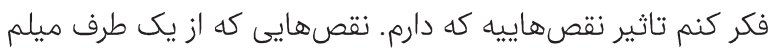

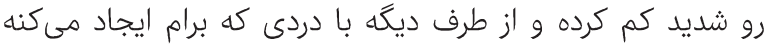

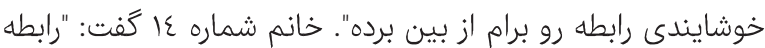

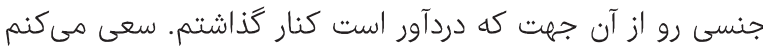
از موقعيتهايى كه اين رابطه رو طلب مىكنه هميشه اجتناب إناب

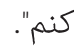

جدول () توزيع فراوانى مطلق و نسبى ويزگىهاى جمعيتشناختى در جانبازان

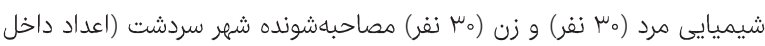

\begin{tabular}{|c|c|c|c|}
\hline كل & زنان & مردان & ويزگىىهاى جمعيتشناختى \\
\hline & & & رده سنى \\
\hline$r r(\mu T / V)$ & $\mathbb{N}\left(\varepsilon_{0} / 0\right)$ & $10(\mu \mu, \mu)$ & مال \\
\hline$r\urcorner(\varepsilon \mu, \mu)$ & $11(\mu\rceil / \vee)$ & $10(0 \% \%)$ & مال \\
\hline \multirow[t]{2}{*}{$\mathbb{I r}\left(\mathrm{r}_{0} / 0\right)$} & $V(\Gamma \mu, \mu)$ & $0(17 / \mathrm{V})$ & مال-1010 سال \\
\hline & & & سطح تحصيلات \\
\hline $1 \varepsilon(\mu, \mu, \mu)$ & $10(\mu \mu, \mu)$ & $\varepsilon(1, \mu, \mu)$ & بىسواد \\
\hline$r r(\mu T / V)$ & $\mathbb{N}\left(\varepsilon_{0} / 0\right)$ & $10(\mu \mu, \mu)$ & زير دييلم \\
\hline$\backslash\left(\mu_{0} / 0\right)$ & $T\left(Y_{0} / 0\right)$ & $\mathbb{I r}\left(\varepsilon_{0} / 0\right)$ & دييلم \\
\hline \multirow[t]{2}{*}{$7(1 \% \%)$} & $r(T / V)$ & $\varepsilon(1 \mu, \mu)$ & تحصيلات دانشگاهى \\
\hline & & & وضعيت اشتغال \\
\hline$r_{0}(\mu \mu, \mu)$ & - & $r_{0}(77 / V)$ & شغل آزاد \\
\hline $17(Y 7 / Y)$ & $T\left(Y_{0} / 0\right)$ & 10 $(\mu \mu, \mu)$ & كارمند \\
\hline$r \varepsilon(\varepsilon \circ / 0)$ & $r \varepsilon\left(\Lambda_{0} \%\right)$ & - & خانهدار \\
\hline \multirow[t]{2}{*}{ - } & - & - & بدون شغل \\
\hline & & & درصد جانبازى \\
\hline $17(Y 7 / Y)$ & $\varepsilon(1 \mu, \mu)$ & $\mathbb{I}\left(\varepsilon_{0} / 0\right)$ & زير بro\% \\
\hline щ $(7 \mu, \mu)$ & $r r(V \mu, \mu)$ & $17(0 \mu, \mu)$ & $\%$ \%т-О。 \\
\hline \multirow[t]{2}{*}{$7(1 \% / 0)$} & $\varepsilon(1 \mu, \mu)$ & $r(7 / V)$ & 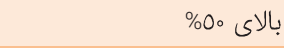 \\
\hline & & & تعداد فرزندان \\
\hline or $(90 / 0)$ & $r \wedge(q, \mu, \mu)$ & $r q(q 7 / V)$ & دارد \\
\hline$\mu(0 / \%)$ & $r(T / V)$ & $1(\mu, \mu)$ & ن \\
\hline
\end{tabular}

اين دو مفهوم ثانويه دربركيرنده ينج مفهوم اوليه بودند كه عبارتند

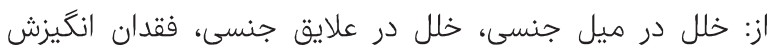

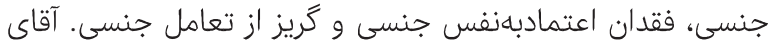

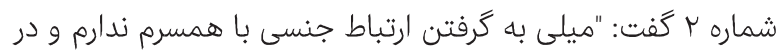

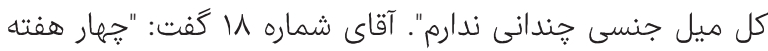

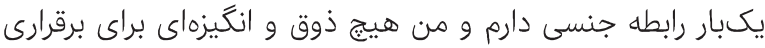

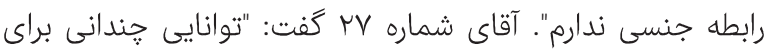

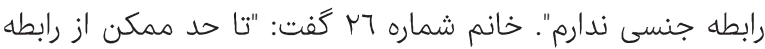

اين زمينه را كاهش داد (به همين دليل V نفر از مصدومان زن حاضر به انجام مصاحبه نشدند). بعد از انجام مصاحبه، ابتدا با كوشدادن بهام به مصاحبههاي انجامشده

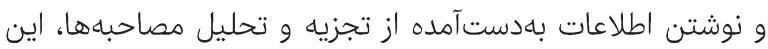
اطلاعات كدكذارى شدند. براى تجزيه و تحليل دادههاى بهدست آحسآدها

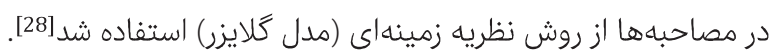

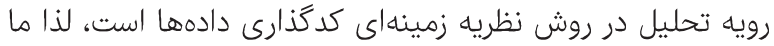

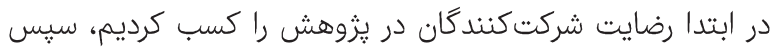
بعد از اجراى مصاحبهها و ضبط مصاحبهها با استفاده از دستكاه ضبط صوت، متن مصاحبهها را روى كاغذ آورديم و كدگذارى دادها دها دادها

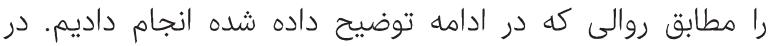

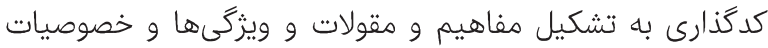

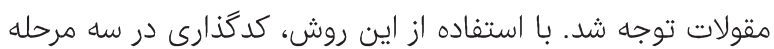
كدگذارى باز يا آزاد، كدگذارى محورى و كدگذارى انتخابى انجام

كدگذارى باز يا آزاد: براى كدگذارى باز يا آزاد، بهصورت مشخص به

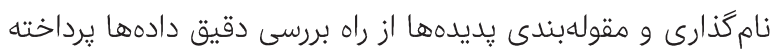

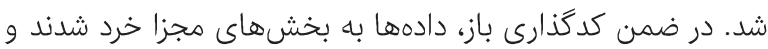

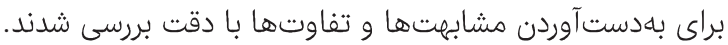

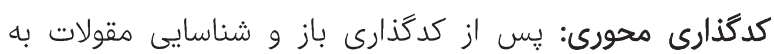

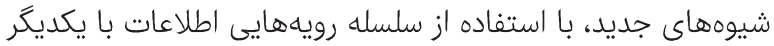

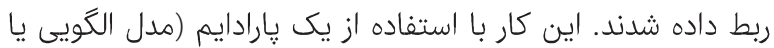

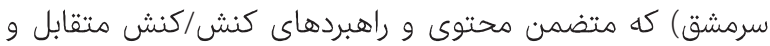

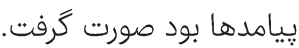

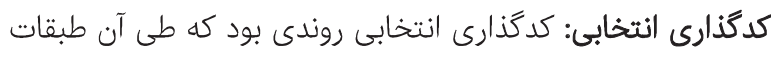

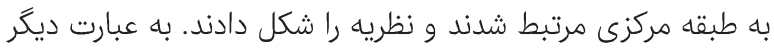

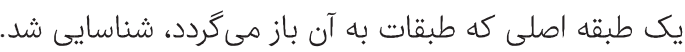

\section{يافتهها}

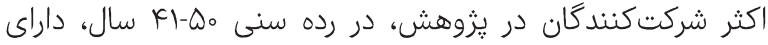

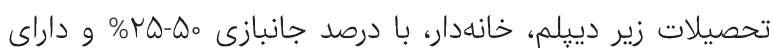

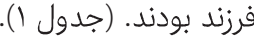

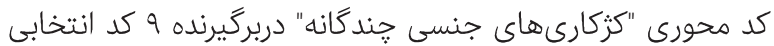

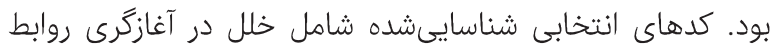

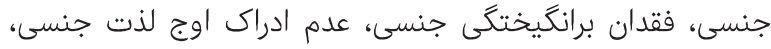

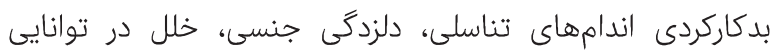

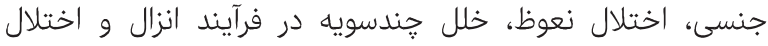
خودارضايى بود كه توام با مفاهيم اوليه و ثانويه خود مورد شناسايى انتلني

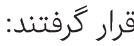
1) خلل در آغازگرى روابط جنسى: اولين كد انتخابى بِيرامون

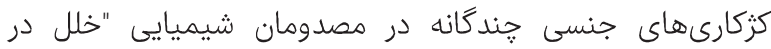

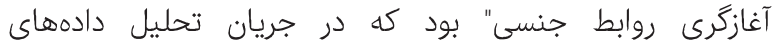

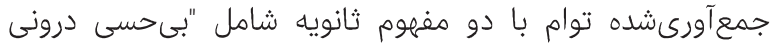
نسبت به روابط جنسى" و "كريز ذهنى و اجتناب عملى از روابط 
امتدادبخشيدن به رابطه جنسى" بود. آقاى شماره r كَفت: "رابطه

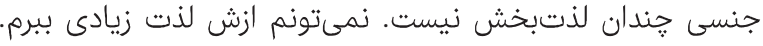

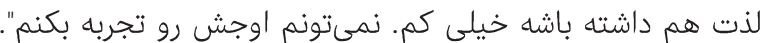

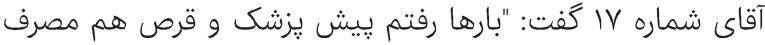

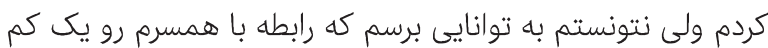

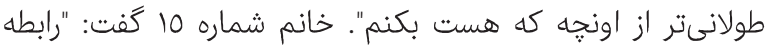

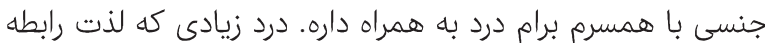

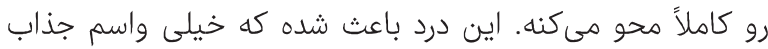

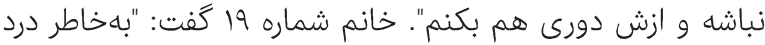

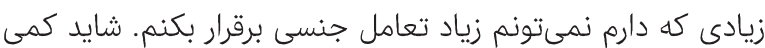

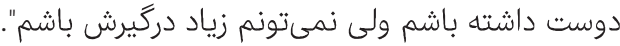

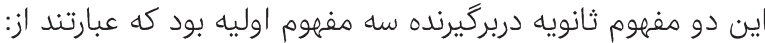

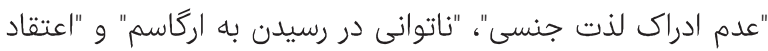

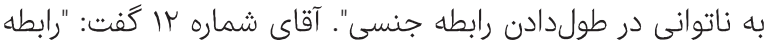
جنسى خيلى لذت نداره برام. تا الان نشده اون طور كه بايد احساس

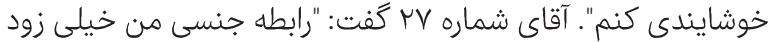

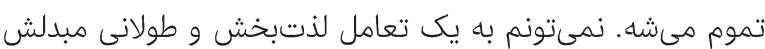

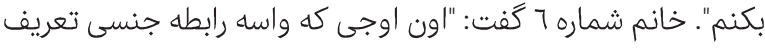
مىكنن رو هيج وقت لمس نكردم". برخى افراد بيان كردندا

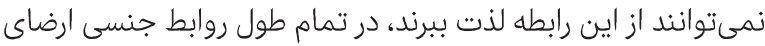

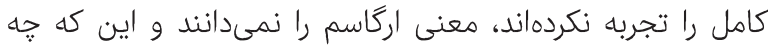

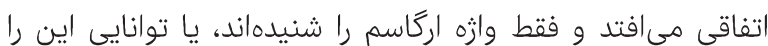
ندارند كه همسرشان را به اركاسم برسانند. ع) بدكاركردى اندامهاى تناسلى يا اختلال درد ناحيه تناسلى:

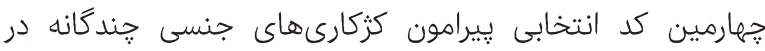

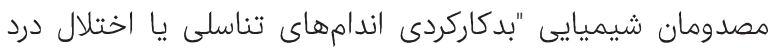

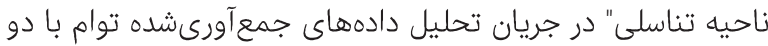
مفهوم ثانويه شامل "ادراك درد تناسلى بدون ردابل رابطه جنسى" و و "ادراك

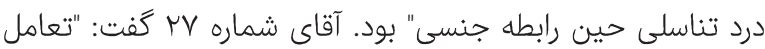

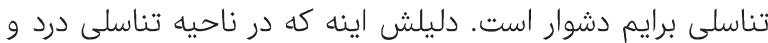
زخم زياد دارم كه اين نمىذاره ارتباط بكيرم". آقاى شماره 7 كَتت:

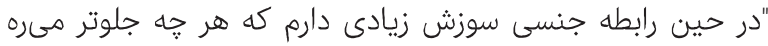

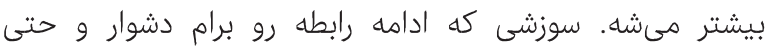

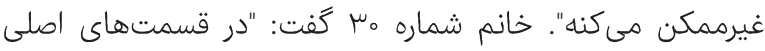
رابطه هميشه درد دارم. اين درد باعث مىشهانه حتى اگر رابطه هم

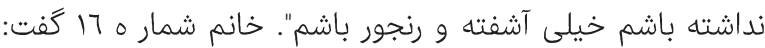

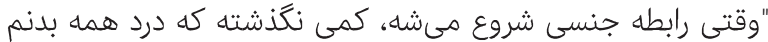
رو مى

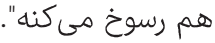
اين دو مفهوم ثانويه دربركيرنده جهار مفهوم اوليه بود كه عبارتند از:

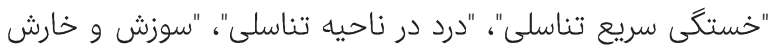

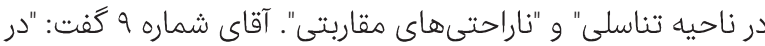

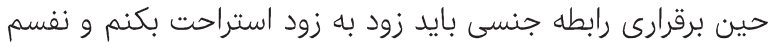

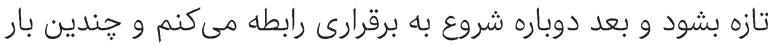

جنسى امتناع مىكنم. هم توانايىاش راش راندارم و هم اين كه زياد

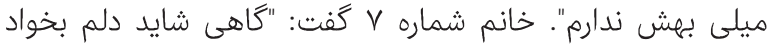

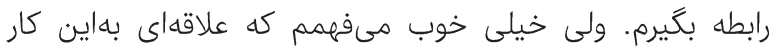

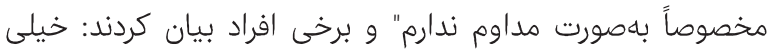
دلشان به برقرارى ارتباط جنسى نميره، رابطه جنسى زيادى ندان ندارند، دليلشم اينه كه خيلى تمايل بهش رنداط ندارند، علايق جنسى خاصنى

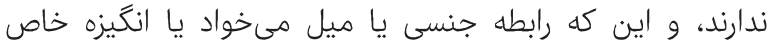

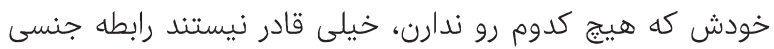
مطلوب ايجاد كنند، يا بهخاطر نقصى كه دارند برقرارى رئ رابطه خيلى

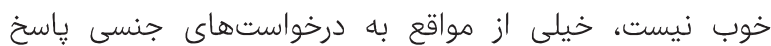
نمى نهند.

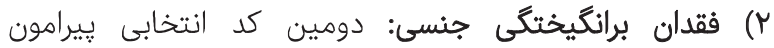

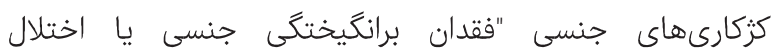

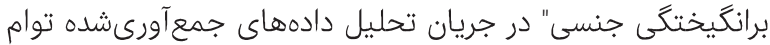

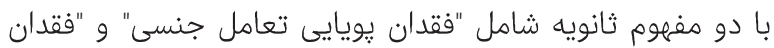

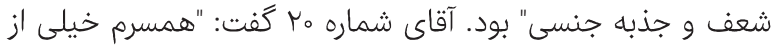

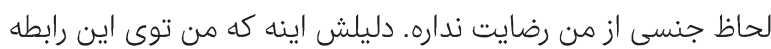

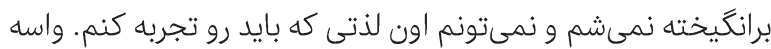

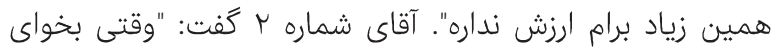

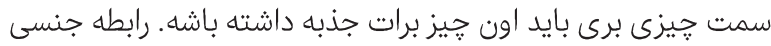
هيج كششى براى من نداره، لذتى هم نداره". خانم شماره سب كَّت:

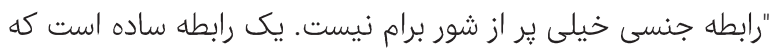

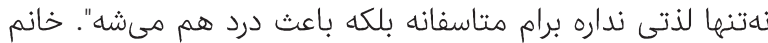

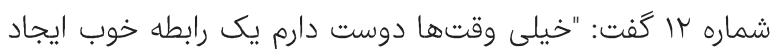
بكنم. تلاش هم مىكنم ولى جون رابطه جنسى و نزديكى، نارا داحتى

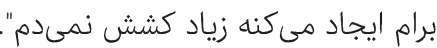

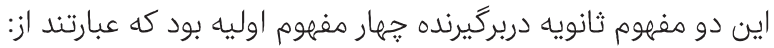

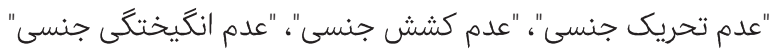

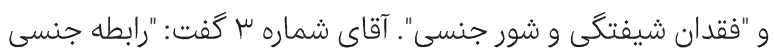

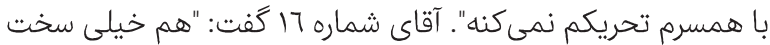

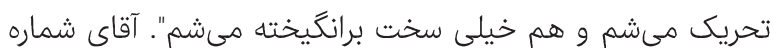

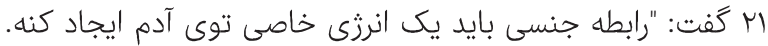

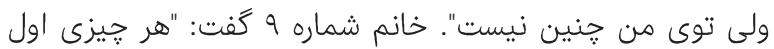

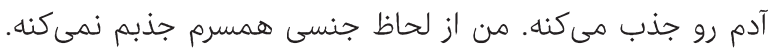

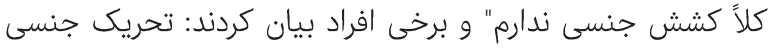

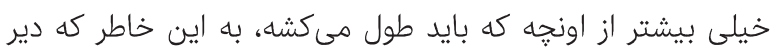

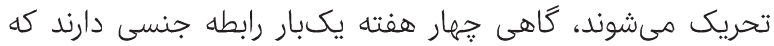
اين باعث شده كه هيج انكيزهاي براى برقرارى رابطه جنسى نداشته

باشند.

سا عدم ادراك اوج لذت جنسى يا اختلال اركاسم: سومين كد

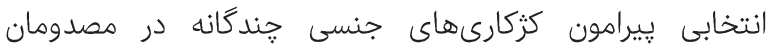

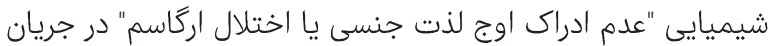

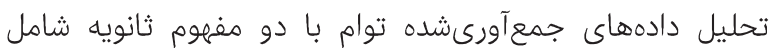

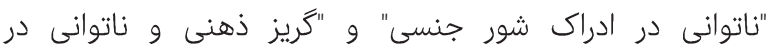




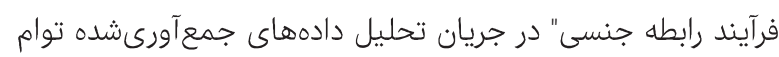

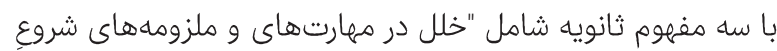

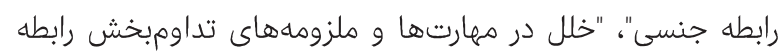

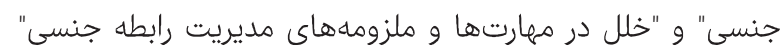

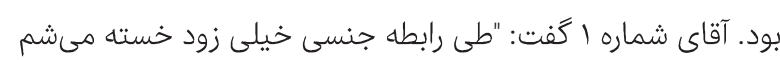

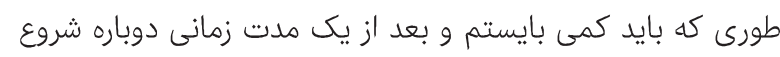

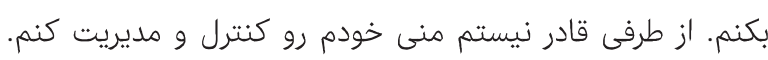

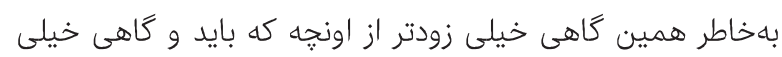

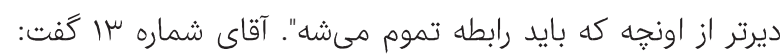

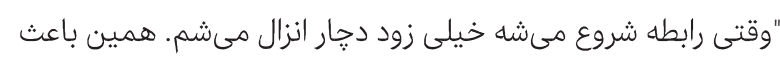

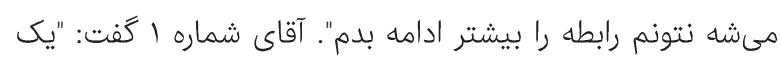

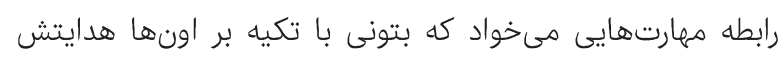

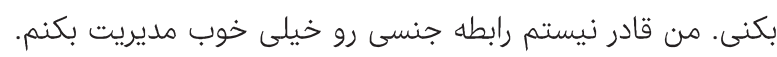

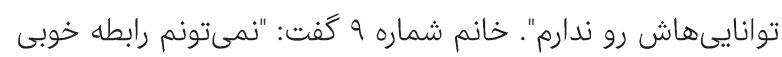

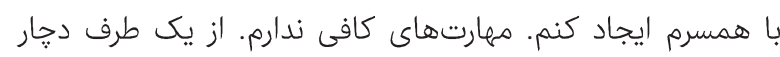

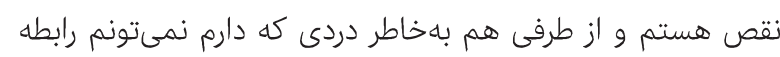

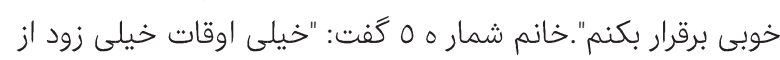

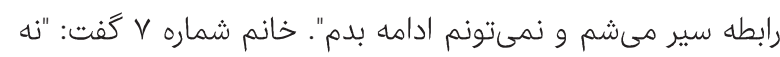

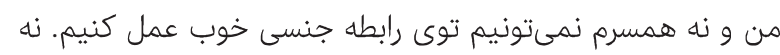
شروع و نه پايانش قاعده مشخصى ندارد".

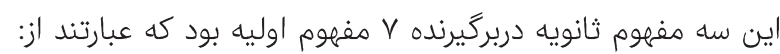

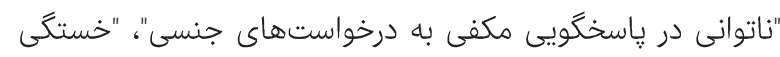

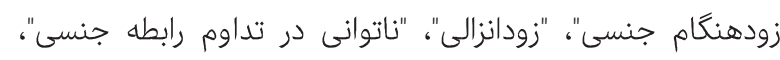

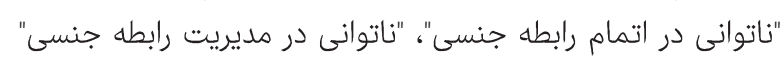

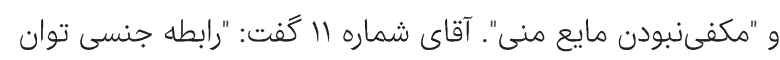

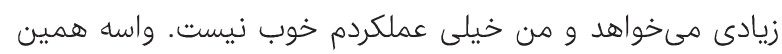

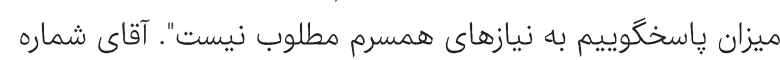

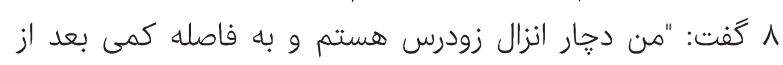

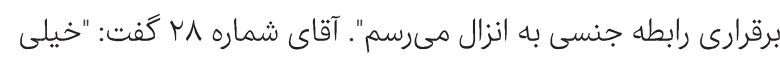

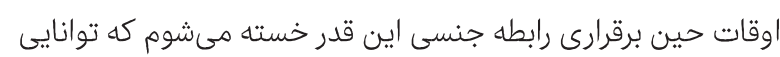

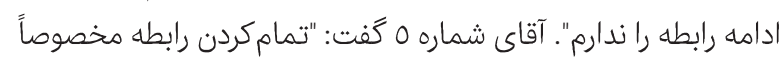

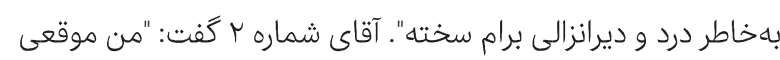

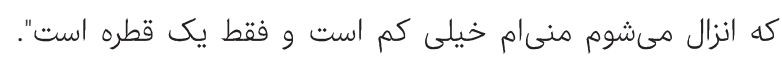

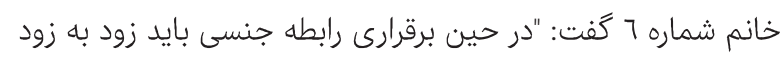

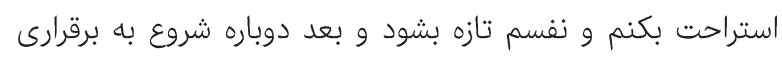

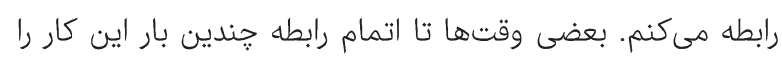

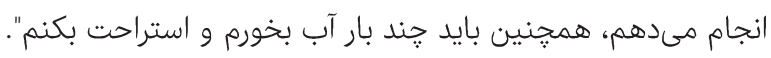

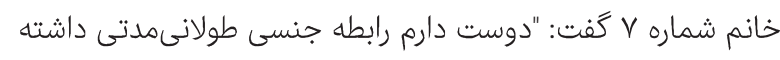

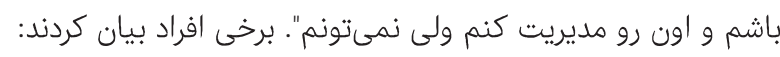

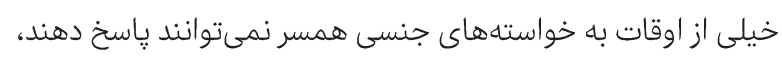

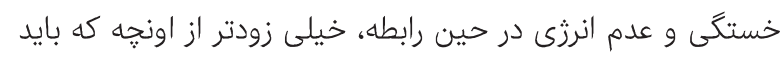

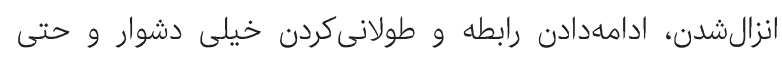

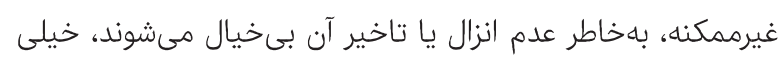
خوب نمىتوانند تعامل جنسى رو با همسر همخوان وخان و همسو بكنيند،
اين كار را انجام مىدهم و اين باعث بيزارى و تنفر من از رابطه

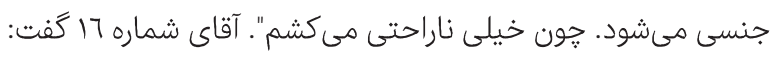

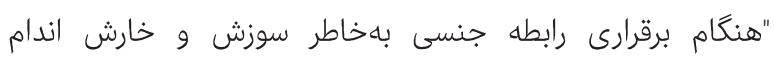

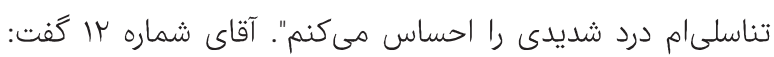

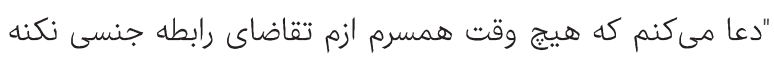

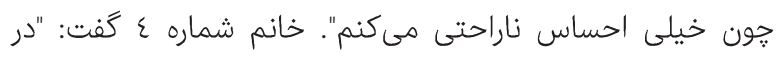

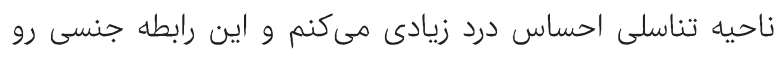

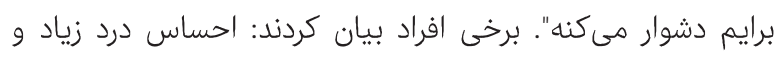

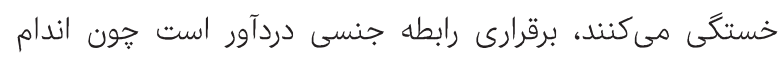

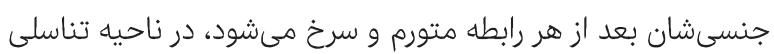

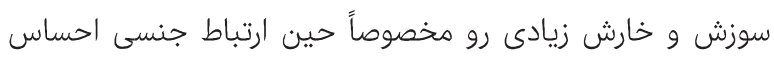

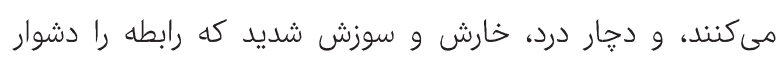

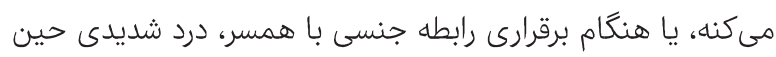

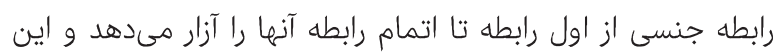
نوع رابطه عذابآور است.

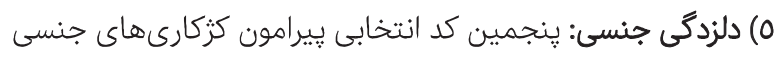

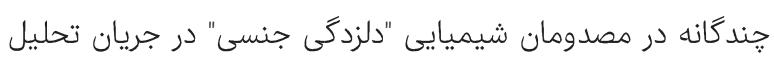

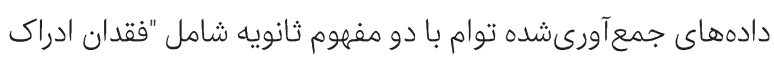

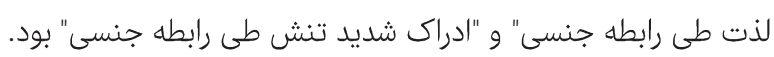

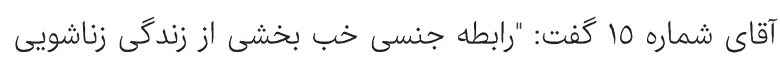

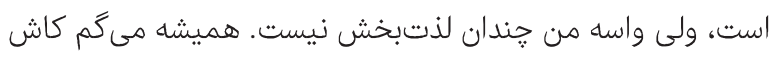

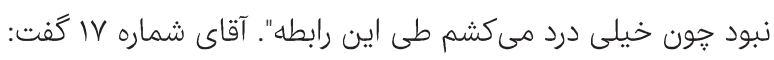

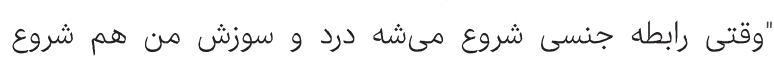

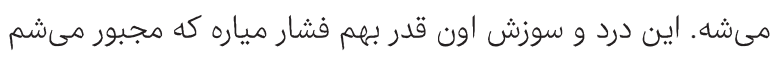

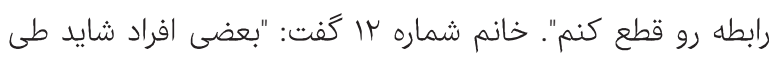

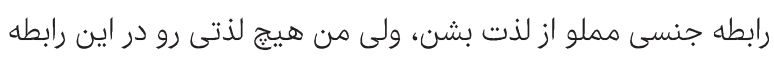

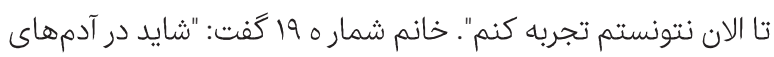

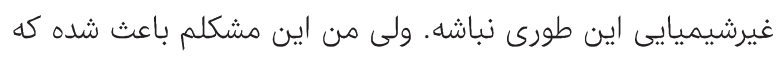

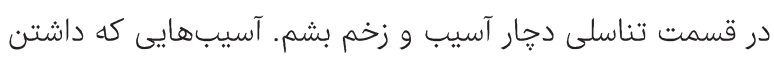

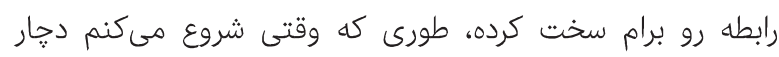

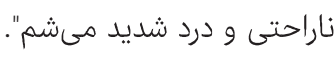

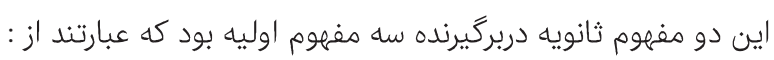

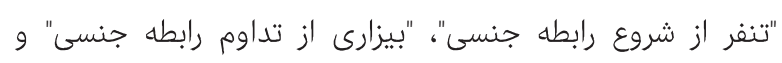

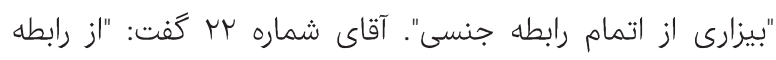

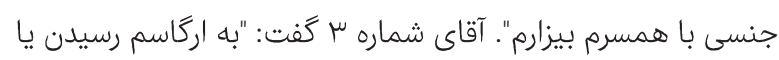

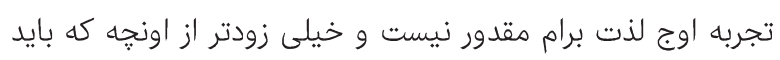

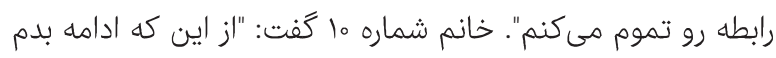

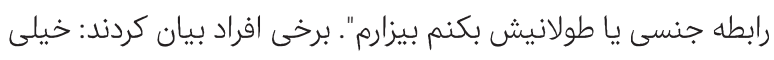

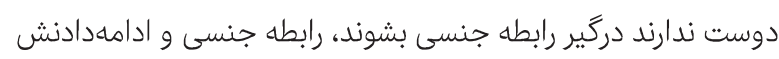

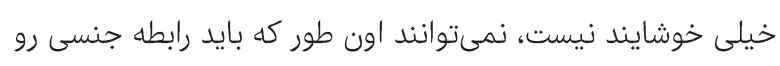

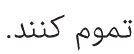
7) خلل در توانايى جنسى يا فقدان ملزومههاى فرآيند رابطه جنسى:

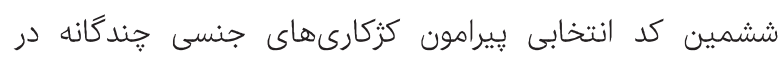

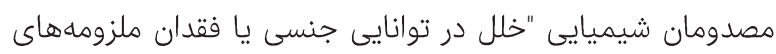


برام خيلى مشكل ايجاد كرده". آقاى شماره ال آكَت: "دوست دارم رابطه جنسى طولانىمدتى داشته باشم، اما متاسفانه هيج كنترلى آنسا

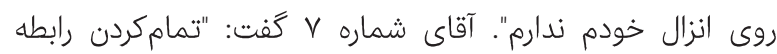

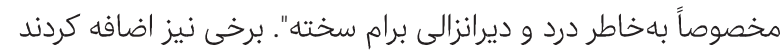

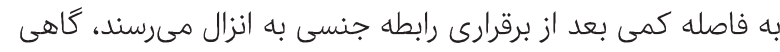

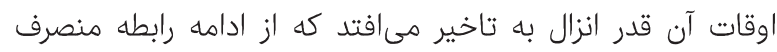

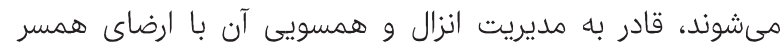

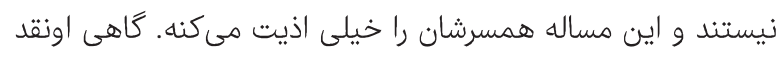

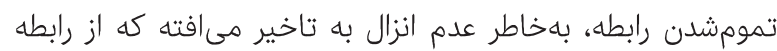

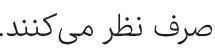
9) اختلال خودارضايى: نهمين و آخرين كد انتخابى پِيرامون

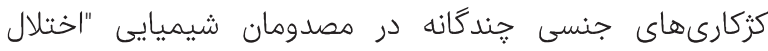
خودارضايى" بود كه در جريان تحليل دادههاى جمعآورىشانده توام ترام

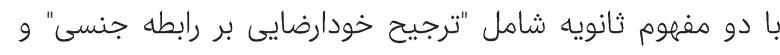

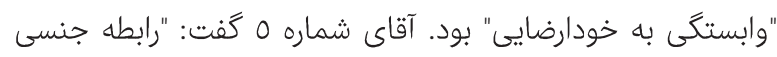

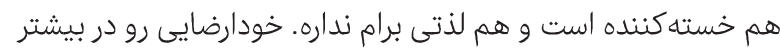

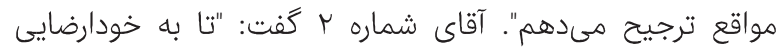
وابسته شدم، اون قدر تكرارش كردم از سر ناجارى كه الان نمىتونم

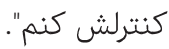

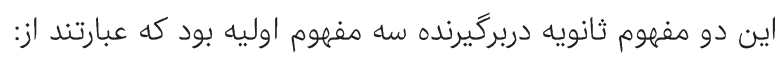

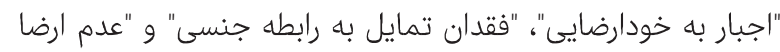

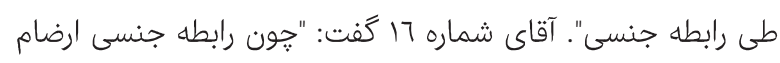

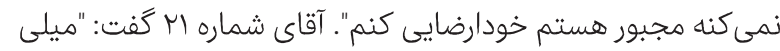

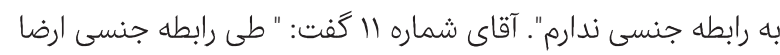

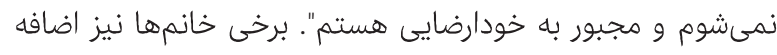

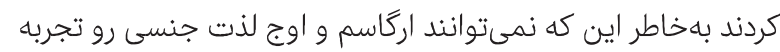

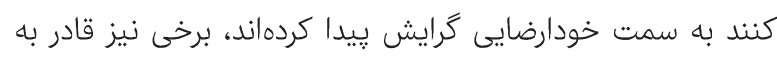

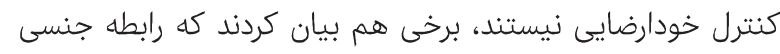

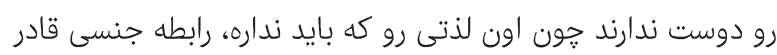

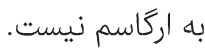

هدف كلى اين يُوهش، بررسى انواع كزكارىهاى جنسى در

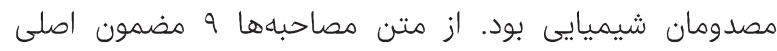

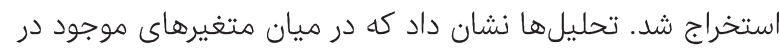

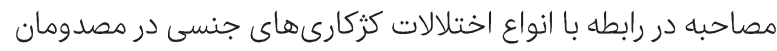

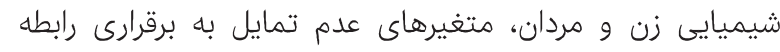

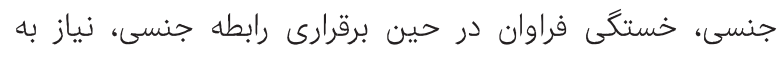

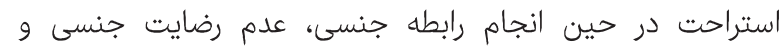

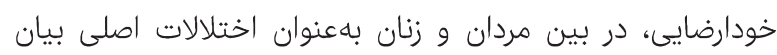

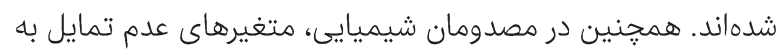

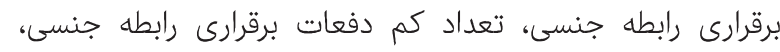

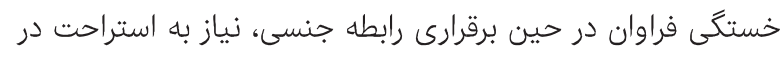

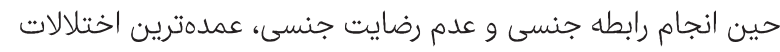

يا مايع منى خيلى كم است يعنى خيلى كمتر از اونجه كه بايد

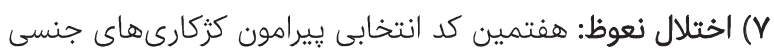

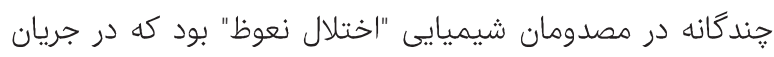

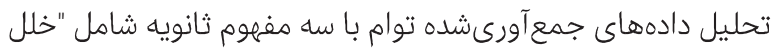

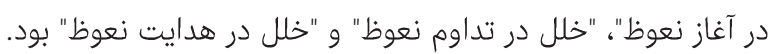

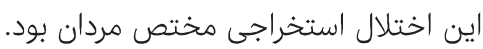

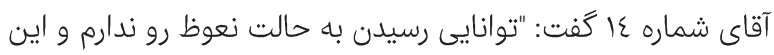

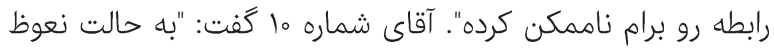

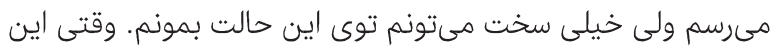

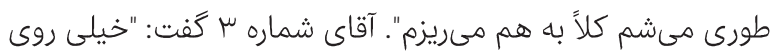

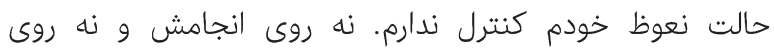

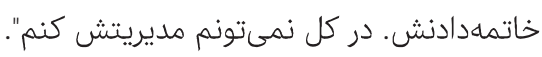

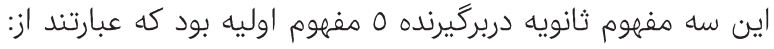

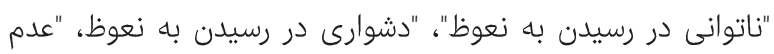

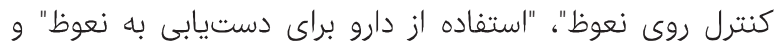

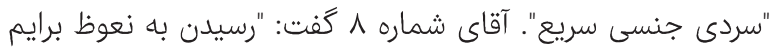

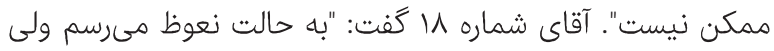

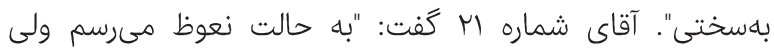

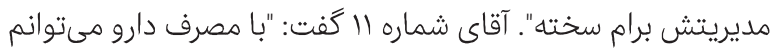

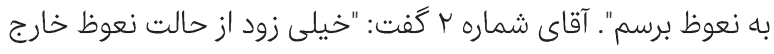

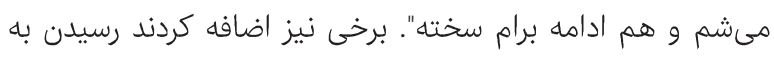

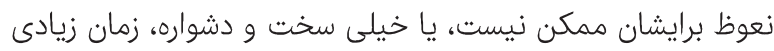

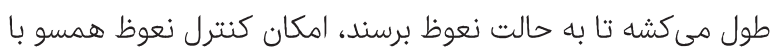
رابطه را ندارند، نعوظ غيرممكن است مكر با باد دارو.

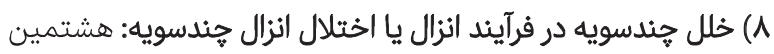

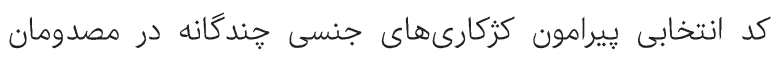

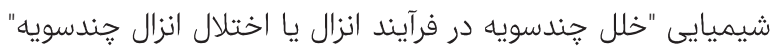

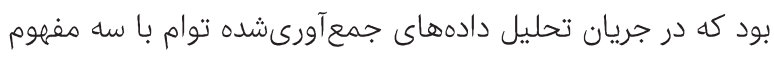

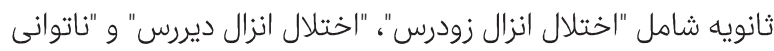

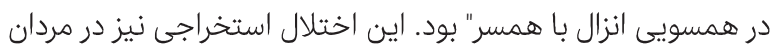

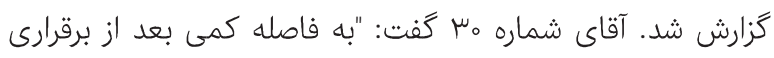

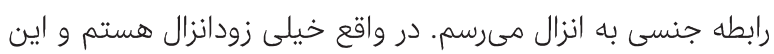

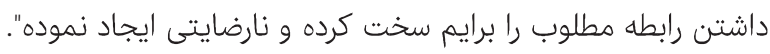

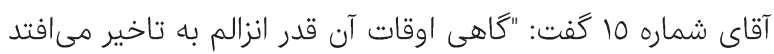

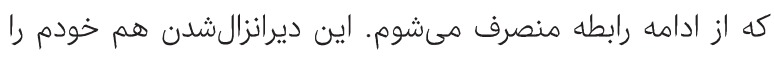

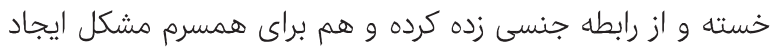

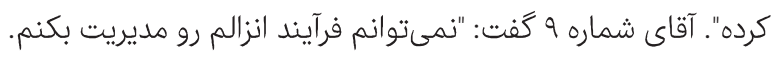

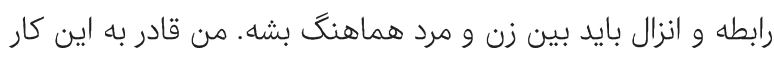

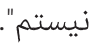
اين سه مفهوم ثانويه دربركيرنده جهار مفهوم اوليه بود كه عبارتند

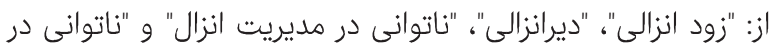

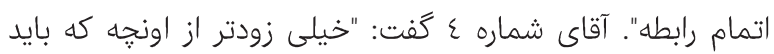

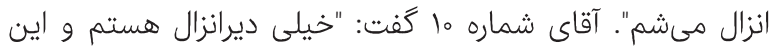




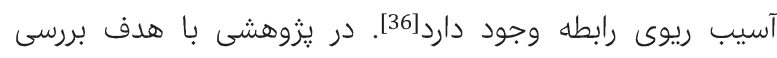

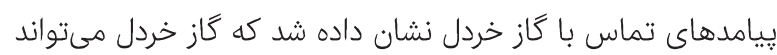

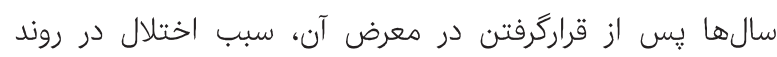

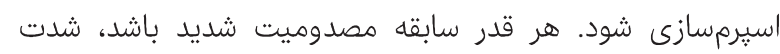

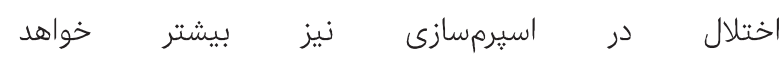

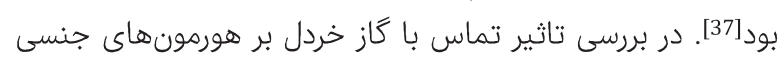

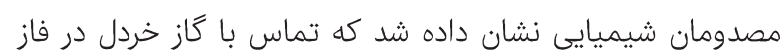

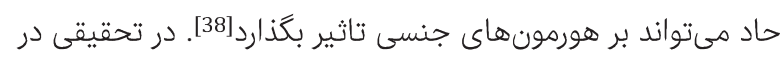

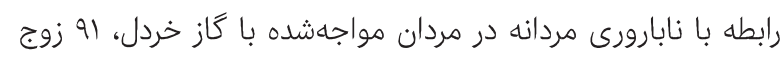

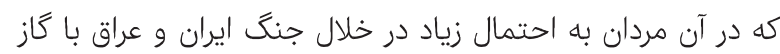

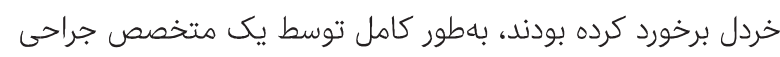

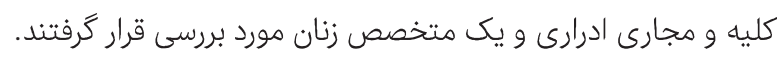

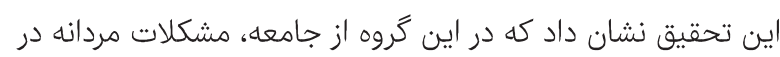

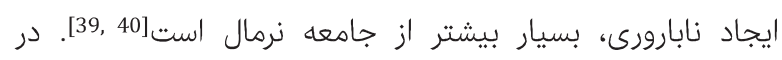

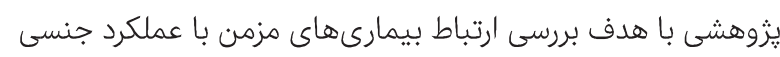

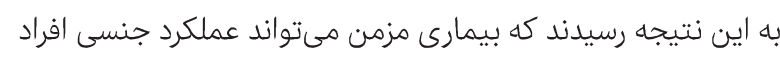

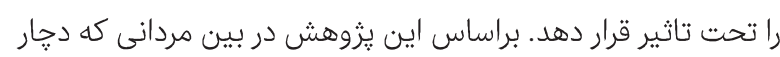

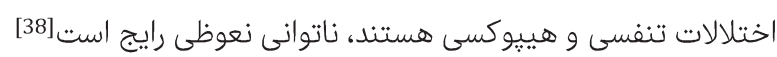

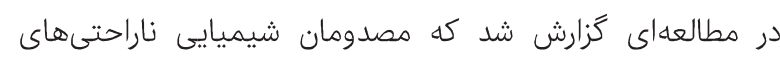

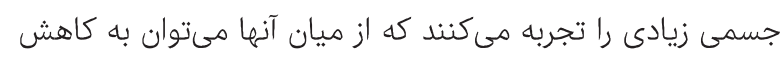

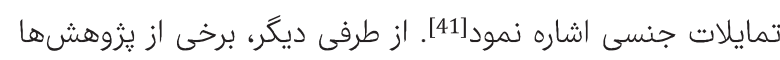

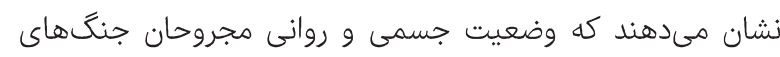

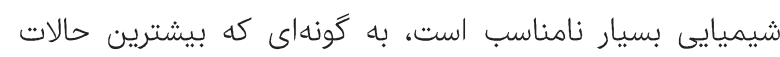

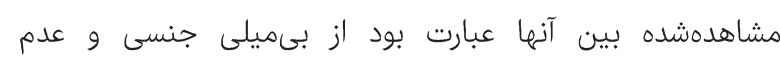

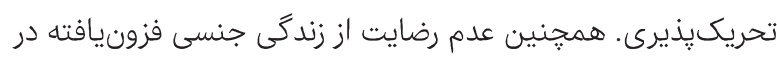
آنان ديده شد [42]. يكى از مهمترين محدوديتهاى اين مطالعه، سئوالات مربوط به به

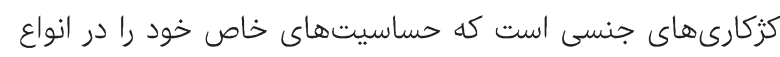

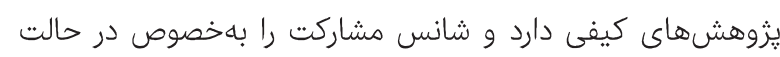

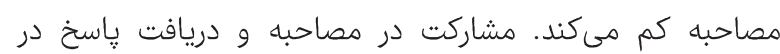

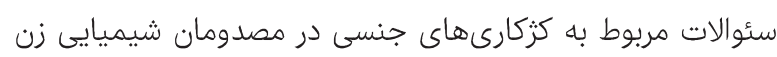

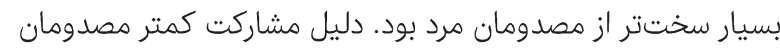

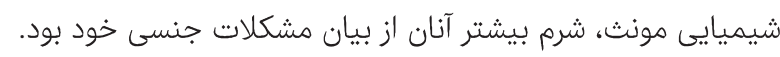

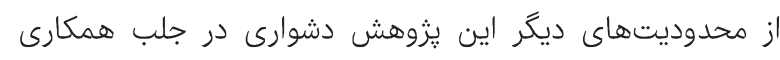

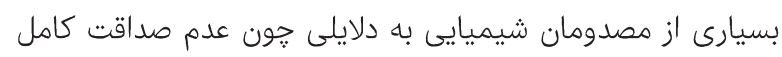

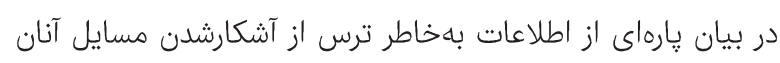

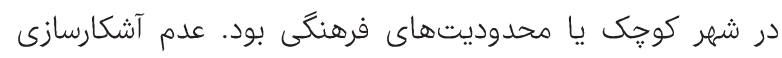

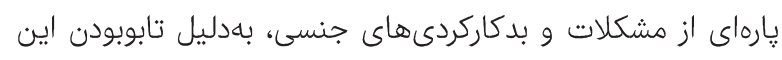

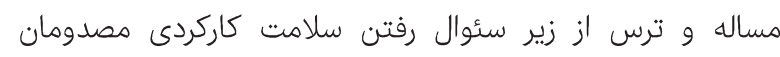

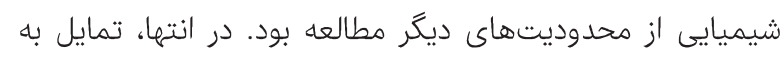

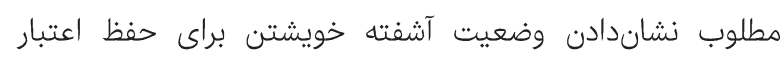
خويش يا عكس آن، نامطلوب نشاندادن وضعيت مطلوب خويشتن

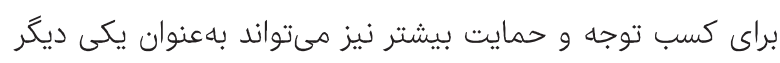
از محدوديتهاى يزوهش حاضر مورد تاكيد قرار گيرد.
كزكارىهاى جنسى در ميان مصاحبهشوندكان مرد بودند. در

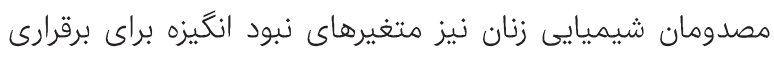

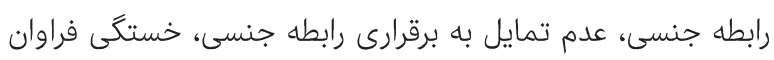

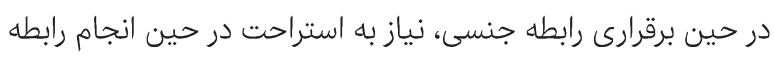

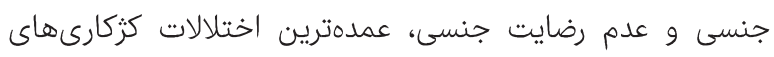

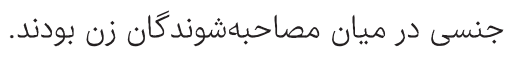

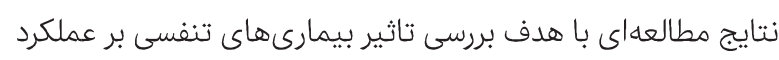

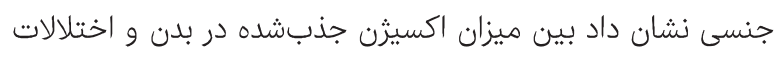

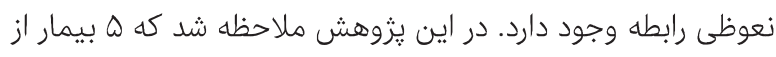

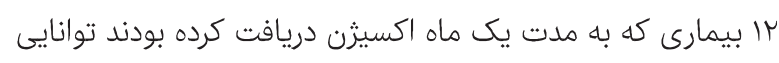
جنسىشان را به دست آوردند. در نتيجه هم ميزان فشار اكسيثن إنه

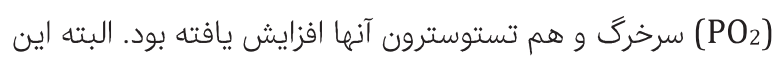

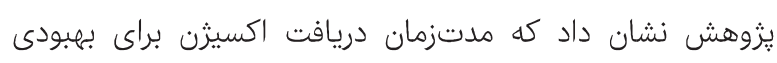

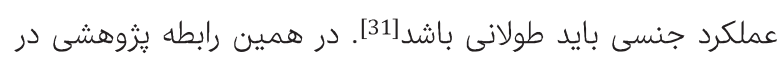
بررسى آسيبديدگان غيرنظامى مواجهشده بايد طولاني باشلاحهاى شيميايى،

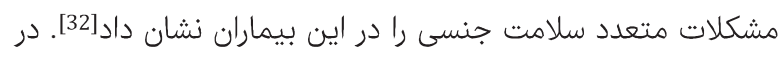

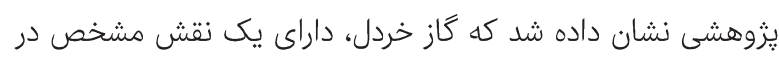

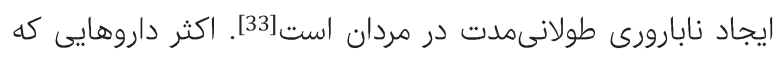
براى كنترل عوارض ضايعات ريوى و اعصاب و روان روان جانبازان مردان

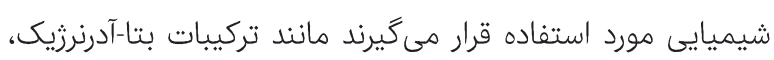

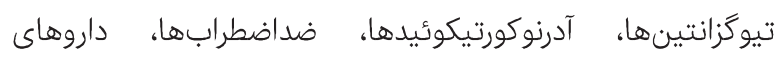

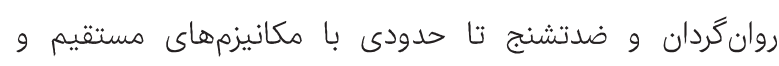
غيرمستقيم و تداخلات دارويى در شكايات جنسى فردئ جانبازان

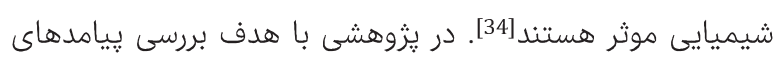
جسمانى و روانشناختى سلاحهاى شيميايى به اين نتايج رسيدند

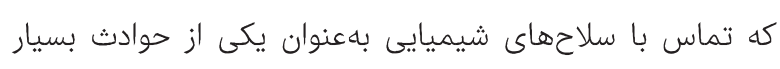

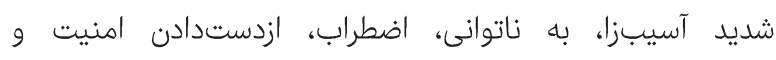

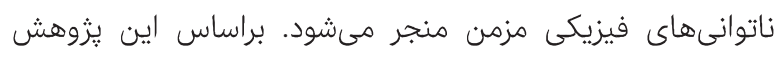
آسيبديدكان غيرنظامى مواجهشده با آثار سلاحهاى شئي منيميايى، داراى كزگكارىهاى جنسى هستند [35].

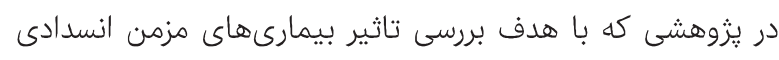

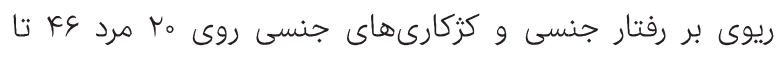

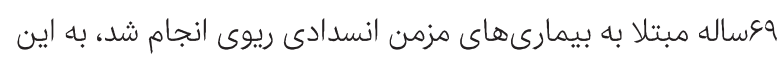

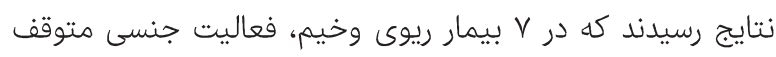

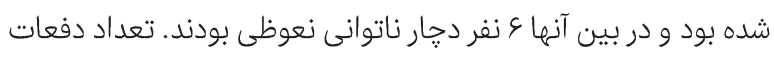

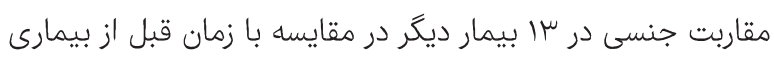

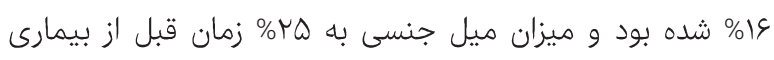

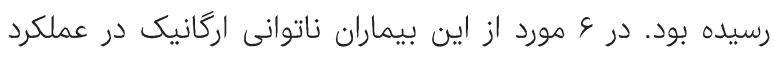

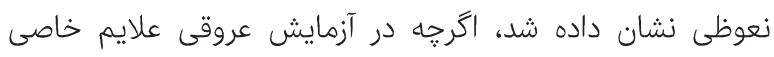

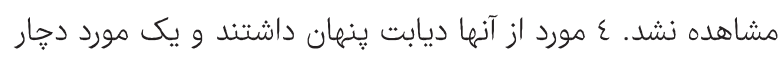

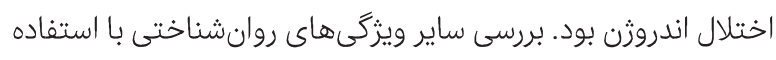

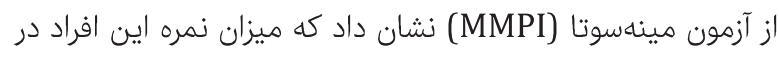

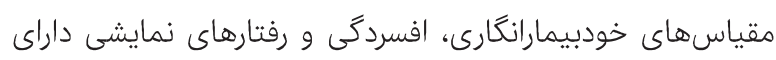

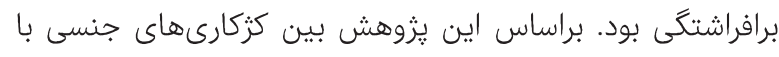


2- Basmenji K. Chemical, microbial and nuclear weapons and ways to deal with it. Tehran: Alamut Publishing. 1985. [Persian]

3- Khateri S, Janati Moheb A. Iraq's use of chemical weapons against Iran UN documents. $1^{\text {st }}$ Edition. Tehran: Foundation for the Preservation of the Works and Publication of the Sacred Defense Values; 2007. [Persian] 4- Starr S, Moulds ML. The role of negative interpretations of intrusive memories in depression. J Affect Disord. 2006;93(1-3):125-32.

5- Ghzanfari T, Yaraei R, Kiasalari Z, Hodaei F, Ghasemi H, Pourfarzam S, et al. Evaluation of serum levels of nitric oxide in chemical victims of Sardsht 20 years after sulfure mustard exposure . Iran J War Public Health. 2009;1(2):923. [Persian]

6- Kordbache Hosseinabad M. The limitation of chemical and biological weapons in international law (with the approach to Iraq's imposed war on Iran). Tehran: Sarir; 2007. [Persian]

7- Nikoobakht MR. Sexual disorders in male and female. Tehran: Tehran University of Medical Sciences Publication; 2003. [Persian]

8- Azizi F. The effect of chemical weaponry on endocrine system. Iran J Endocrinol Metab. 2001;3(3):211-22.

9- Tavallaei SA, Assari S, Najafi M, Habibi M, Ghanei M. Study of sleep quality in chemical-warfare-agents exposed veterans. J Mil Med. 2005;6(4):241-8. [Persian]

10- Barlow HD, editor. Clinical handbook of psychological disorder: A step by step treatment manual. $5^{\text {th }}$ Edition. New York: The Guilford Press; 2014.

11- Nikpour S, Javaheri I, Yadavar Nikravesh M, Jamshidi R. Study of sexual problems resulting from delivery in primiparous women referred to outpatient clinics in west of Tehran . Razi J Med Sci. 2006;13(50):189-96. [Persian] 12- Goshtasbi A, Vahdaninia M, Rahimi Foroushani A, Mohammmadi A. Sexual dysfunction disorders and their relation to fertility variables in Kohgiluyeh and Boyerahmad province. Payesh. 2008;7(1);67-73. [Persian]

13- Sadok BJ, Sadok VA. Kaplan and Sadock's synopsis of psychiatry: behavioral sciences/clinical psychiatry. Volume 2. $10^{\text {th }}$ Edition. Pourafkari N, translator. Tehran: Shahr-e Ab; 2011. [Persian]

14- Rosen RC, Bachmann GA. Sexual well-being, happiness, and satisfaction, in women: the case for a new conceptual paradigm. J Sex Marital Ther. 2008;34(4):2917.

15- Shindel AW, Nelson CJ, Naughton CK, Ohebshalom M, Mulhall JP. Sexual function and quality of life in the male partner of infertile couples: prevalence and correlates of dysfunction. J Urol. 2008;179(3):1056-9.

16- Monga M, Alexandrescu B, Katz SE, Stein M, Ganiats T. Impact of infertility on quality of life, marital adjustment, and sexual function. Urology. 2004;63(1):126-30.

17- Nene UA, Coyaji K, Apte H. Infertility: a label of choice in the case of sexually dysfunctional couples. Patient Educ Couns. 2005;59(3):234-8.

18- Malkari B, Karimian N. Psychological- social consequences chemical bombardment of the Sardasht victims (a qualitative study). Iran J War Public Health. 2013;5(3):7-13. [Persian]

19- Pastor Z. Female sexual desire disorders--prevalence, classification and treatment possibilities. Ceska Gynekol. 2011;76(1):59-64. [Czech]

20- Ranjebar Shayan H, Ahmadi Kh, Raeisi F. Sexual dysfunctions in chemical injured veterans. J Mil Med. [Persian] نتايج نشان داد كزكارىهاى جنسى درال در مصدومان شيميايى شهر

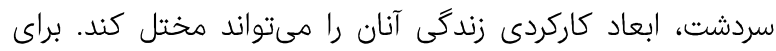

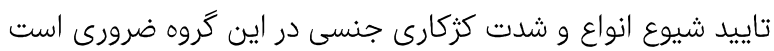

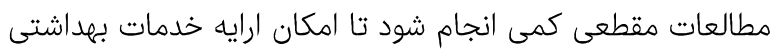

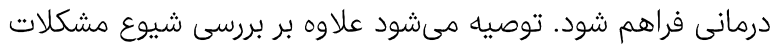

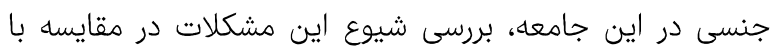

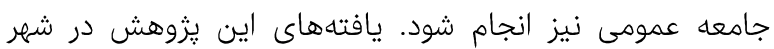

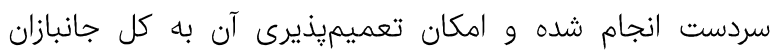

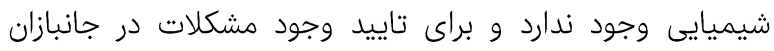
شيميايى جنگ، انجام يزوهشى مقطعى در سطح كشور ضرورى نايدى

\section{نتيجه گيرى}

كزكارىهاى جنسى شناسايى شده در مصدومان شيميايى شهر

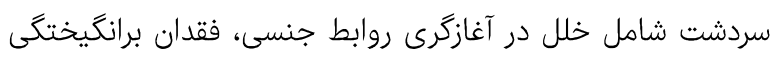

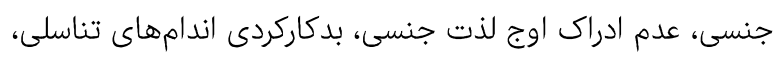

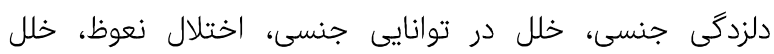
جندسويه در فرآيند انزال و اختلال خودارضايى بودند.

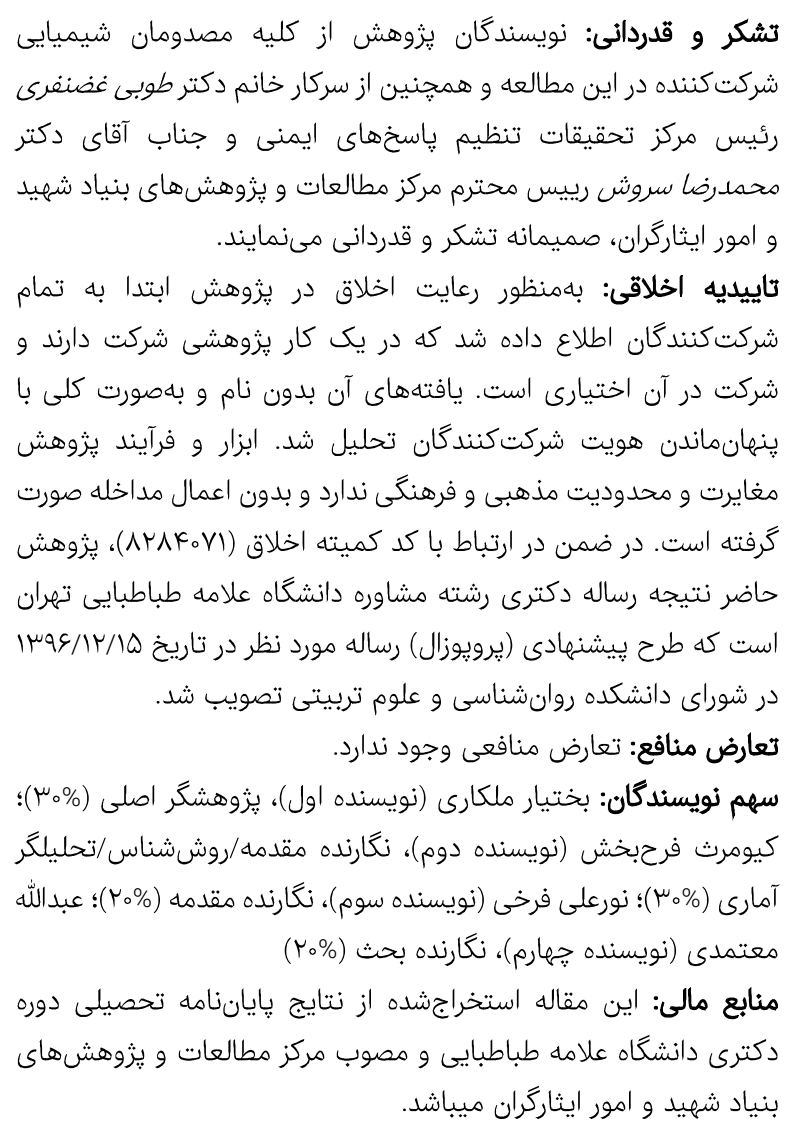


بديدارشناسى كرَكارىهاى جنسى در مصدومان شيميايى شهر سردشت س V

MA, Attari Y. The Effectiveness of cognitive - behavioral therapy and therapeutic therapy in treatment of early ejaculation men referring to Ahwaz Medical Centers. J Fam Couns Psychother. 2013;2(4):435-55. [Persian] 33- Pierre A. Psychological and interpersonal dimensions of sexual function and dysfunction. Arab J Urol. 2013;11(3):217-21.

34- Andrews G. Womens sexual health. $2^{\text {nd }}$ Edition. London: Baillière Tindall; 2001.

35- Brezsnyak M, Whisman MA. Sexual desire and relationship functioning: the effects of marital satisfaction and power. J Sex Marital Ther. 2004;30(3):199-217.

36- Nappi RE, Albani F, Vaccaro P, Gardella B, Salonia A, Chiovato $\mathrm{L}$, et al. Use of the Italian translation of the Female Sexual Function Index (FSFI) in routine gynecological practice. Gynecol Endocrinol. 2008;24(4):214-9.

37- Eskandari M. Investigation of the mental status of chemical agents. In: Proceedings of the National Congress of Military Medicine (with emphasis on 8 years of sacred experience); 2002 Oct 7-9; Tehran, Iran. Tehran: Imam Hussein University; 2002. [Persian]

38- Kargar H. A survey on the relative frequency of sexual dysfunctions in war veterans [Dissertation]. Tehran: Tehran University of Medical Sciences; 2004. [Persian] 39- Jensen P, Jensen SB, Sørensen PS, Bjerre BD, Rizzi DA, Sørensen AS, et al. Sexual dysfunction in male and female patients with epilepsy: a study of 86 outpatients. Arch Sex Behav. 1990;19(1):1-14.

40- Maleknejad M, Fazel F. Examining the problems and complaints of chemical veterans. In: Soroush MR, Majdinasab M, editors. Proceedings of the First Congress on the Consequences of Gas Attacks during Iraq-Iran War; 2004 July 1-2; Tehran, Iran. Tehran: Publications of the Society for the Protection of Chemical Weapons Victims; 2004. [Persian]

41- Ahmadi K, Reshadatjoo M, Karami, G, Anisi J. Vicarious PTSD in Sardasht chemical warfare victims' wives. J Behav Sci. 2009;3(3):195-9. [Persian]

42- Qanei M, Khateri S, Tarighati OR. A health care guide for chemical warfare victims (and their health care providers). $1^{\text {st }}$ Edition. Tehran: Research Institute of Veterans Engineering and Medical Sciences; 2003. [Persian]
2008;10(2):99-106. [Persian]

21- Leiblum SR. Sexual problems and dysfunction: epidemiology, classification, and risk factors. J Gend Specif Med. 1999;2(5):41-5.

22- Basson R, Rees P, Wang R, Montejo AL, Incrocci L. Sexual function in chronic illness. J Sex Med. 2010;7(1 Pt 2):374-88.

23- Beyer CE, Ogletree RJ, Ritzel DO, Drolet JC, Gilbert SL, Brown D. Gender representation in illustrations, text, and topic areas in sexuality education curricula. J Sch Health. 1996;66(10):361-4

24- D'Emilio J, Freedman EB. Intimate matters: a history of sexuality in America. $3^{\text {rd }}$ Edition. London: The University of Chicago Press; 2012

25- Grant JE, Pinto A, Gunnip M, Mancebo MC, Eisen JL, Rasmussen SA. Sexual obsessions and clinical correlates in adults with obsessive-compulsive disorder. Compr Psychiatry. 2006;47(5):325-9.

26- Lewis RW, Fugl-Meyer KS, Bosch R, Fugl-Meyer AR, Laumann EO, Lizza E, Martin-Morales A. Epidemiology/risk factors of sexual dysfunction. J Sex Med. 2004;1(1):35-9.

27- del Mar Sánchez-Fuentes M, Santos-Iglesias P, Sierra JC. A systematic review of sexual satisfaction. Int J Clin Health Pychol. 2014;14(1):64-75.

28- Abu Shosha GM. Employment of Colaizzi's strategy in descriptive phenomenology: a reflection of a researcher. Eur Sci J. 2012;8(27):31-43.

29- Nourmohammadi B. Neuropsychological status in chemical warfare veterans with chronic PTSD disorder. In: Soroush MR, Majdinasab M, editors. Proceedings of the First Congress on the Consequences of Gas Attacks during Iraq-Iran War; 2004 July 1-2; Tehran, Iran. Tehran: Publications of the Society for the Protection of Chemical Weapons Victims; 2004. [Persian]

30- Yousefi N, Farsani K, Shakiba A, Hemmati S, Nabavi Hesar J. Halbert index of sexual desire (HISD) questionnaire validation. Clin Psychol Pers. 2014;2(9):107-18. [Persian]

31- Fahlbusch E, Lochman JM, Mbiti J, Pelikan J, Vischer L, Bromiley GW, et al. The encyclopedia of Christianity. Volume 4. Michigan: Eerdmans Publishing Company; 2005.

32- Rajabi GR, Amanollahi A, Khojest Mehr R, Hosseini 